Florida International University FIU Digital Commons

$1-29-1997$

\title{
Effect of child care subsidies on price and quality of care for low-income families
}

Sudhersena Alalasundaram

Florida International University

DOI: $10.25148 /$ etd.FI13101558

Follow this and additional works at: https://digitalcommons.fiu.edu/etd

Part of the Public Administration Commons

\section{Recommended Citation}

Alalasundaram, Sudhersena, "Effect of child care subsidies on price and quality of care for low -income families" (1997). FIU Electronic Theses and Dissertations. 1181.

https://digitalcommons.fiu.edu/etd/1181

This work is brought to you for free and open access by the University Graduate School at FIU Digital Commons. It has been accepted for inclusion in FIU Electronic Theses and Dissertations by an authorized administrator of FIU Digital Commons. For more information, please contact dcc@fiu.edu. 


\section{FLORIDA INTERNATIONAL UNIVERSITY}

Miami, Florida

\section{EFFECT OF CHILD CARE SUBSIDIES ON PRICE AND QUALITY OF CARE FOR LOW-INCOME FAMILIES}

A dissertation submitted in partial satisfaction of the

requirements for the degree of

DOCTOR OF PHILOSOPHY

IN

PUBLIC ADMINISTRATION

by

Sudhersena Alalasundaram

1997 
To: Dean Mark Rosenberg

College of Urban and Public Affairs

This dissertation, written by Sudhersena Alalasundaram, and entitled Effect of Child Care Subsidies on Price and Quality of Care for Low-Income Families, having been approved in respect to style and intellectual content, is referred to you for judgement.

We have read this dissertation and recommend that it be approved.

Frederick Newman

JameşCarroh, Major Professor (Co-Chairperson)

A $n$ Dryden Witte Major Professor (Co-Chairperson)

Date of Defense: January 29, 1997

The dissertation of Sudhersena Alalasundaram is approved.

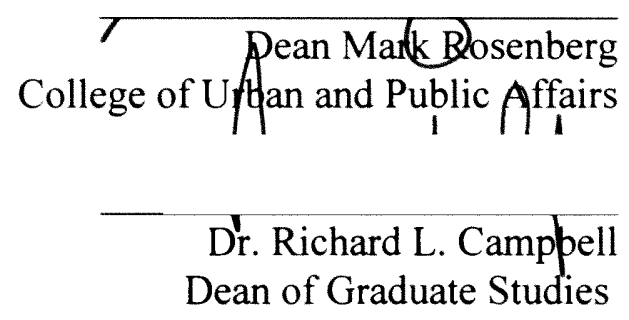

Florida International University, 1997 
I dedicate this dissertation to my parents, Vasantha and Kandaswamy Alalasundaram. 


\section{ACKNOWLEDGMENTS}

I wish to thank the members of my committee for their helpful comments and patience. A special thanks must go to Dr. Ann Witte, for her support and encouraging comments. I wish to thank Dr. James Carroll for his encouragement and timely help and Dr. Frederick Newman for his help with the graphs. I also want to thank Dr. Howard Frank for the financial support which enabled me to complete this dissertation successfully. I also wish to express my gratitude to the library staff at FIU, North Campus for their cooperation in helping me locate material in the library. Last but not the least, a special thanks must go to Teresa Moloney-Bini for her friendship and constant encouragement. 


\section{ABSTRACT OF THE DISSERTATION \\ EFFECT OF CHILD CARE SUBSIDIES ON PRICE AND QUALITY OF CARE FOR LOW-INCOME FAMILIES}

by

Sudhersena Alalasundaram

Florida International University, 1997

Professor Ann Dryden Witte, Major Professor (Co-Chairperson)

Professor James Carroll, Major Professor (Co-Chairperson)

This dissertation examines the effect of regulations, resource and referral agencies, and subsidies on price and quality of care in child care centers. This research is based on a carefully developed conceptual framework that incorporates the factors affecting the demand and supply of child care. The first step in developing this framework is sketching out the structural equations. The structural equations help us understand the underlying behavior of individuals and firms making a decision. The exogenous variables are vector of attributes relating to family characteristics, child characteristics, regulations, subsidy, community characteristics and prices of inputs. Based on the structural equations, reduced form equations are estimated to find the effect of each of the exogenous variables on each of the endogenous variables. Reduced form equations help us answer public policy questions. The sample for this study is from the 1990 Profile of Child Care Settings (PCCS) data in which 2,089 center based programs 
were interviewed.

Child/Staff Ratio (Group Level): Results indicate that among subsidies, only the state subsidy per child in poverty has a significant effect on the child/staff ratio at the group level. Presence of resource and referral agencies also increase the child/staff ratio at the group level. Also when the maximum center group size regulation for 25-36 months becomes more stringent, the child/staff ratio at the group level decreases.

Child/Staff Ratio (Center Level): When the regulations for the maximum child/staff ratio for age groups 13-24 months and 37-60 months become lax, the child/staff ratio for the center increases. As the regulation for maximum group size for infants becomes stringent, the child/staff ratio decreases. An interesting finding is that as the regulations for maximum group size for age groups 13-24 months and 25-36 months become stringent, the child/staff ratio for the center increases. Another significant finding is that when a center is located in a rural area the child/staff ratio is significantly lower. Center Weighted Average Hourly Fees: Maximum group size regulations for age groups 25-36 months and 37-60 months have a negative effect on center hourly fee. Maximum child staff regulations for age groups 13-24 months and 37-60 months have a negative effect on center hourly fee. Maximum child staff regulations for age groups 0-12 months and 25-36 months have a positive effect on center hourly fee. Findings also indicate that the center average hourly price is lower when there is a resource and referral agency present. Cost adjusted prekindergarten funds and JOBS child care subsidies have a negative effect on average hourly fee. Cost adjusted social services block grant and state 
subsidy per child in poverty have a positive effect on the average hourly price. A major finding of this dissertation is the interaction of subsidy and regulatory variables.

Another major finding is that child/staff ratio at the group level is lower when there is an interaction between geographic location and nature of center sponsorship. 


\section{TABLE OF CONTENTS}

Chapter I- Issues and Objectives.

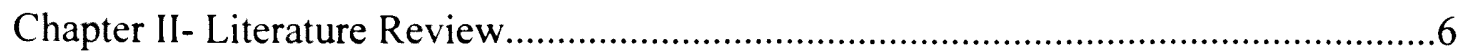

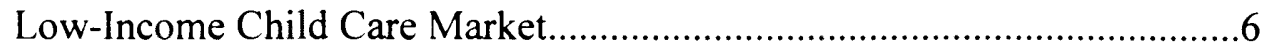

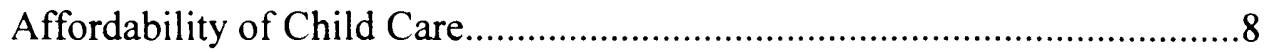

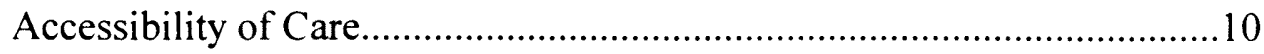

Quality of Care

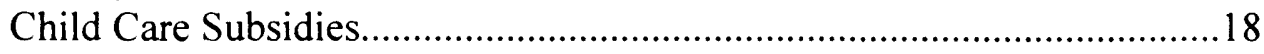

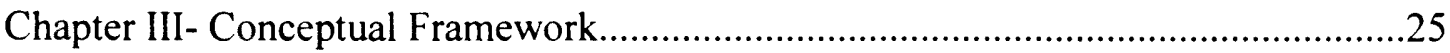

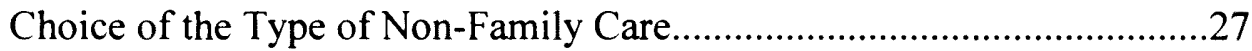

Demand and Supply of Child Care ......................................................28

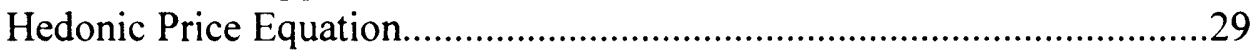

Reduced Form Equations....................................................................30

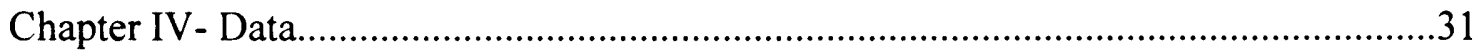

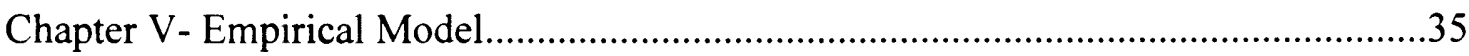

Functional Form and Statistical Analysis.................................................50

Chapter VI- Empirical Results and Policy Implications...............................................68

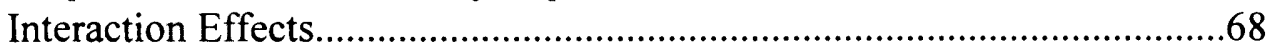

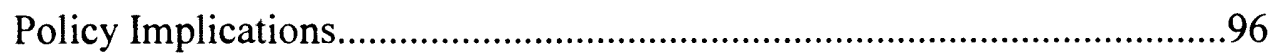

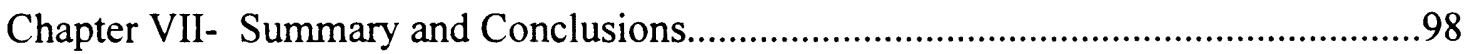

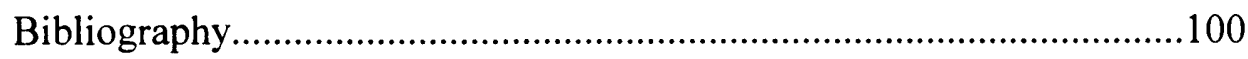




\section{LIST OF TABLES}

Table 1- Data

Table 2- Dependent and Explanatory Variables..............................................................38

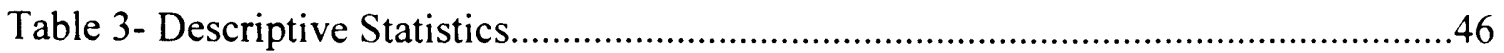

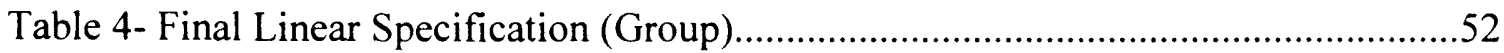

Table 5- Final Linear Specification (Child/Staff Ratio).................................................54

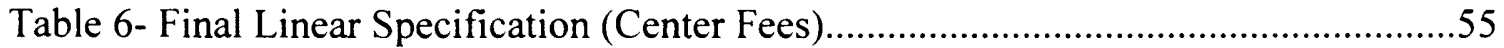

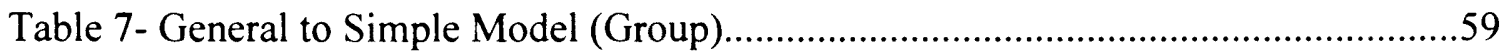

Table 8- General to Simple Model (Child/Staff Ratio)..................................................61

Table 9- General to Simple Model (Center Fees)..........................................................62

Table 10- Non Linear Specification (Group)...............................................................64

Table 11 - Non Linear Specification (Child/Staff Ratio)..................................................65

Table 12- Non Linear Specification (Center Fees)..........................................................66 


\section{LIST OF FIGURES}

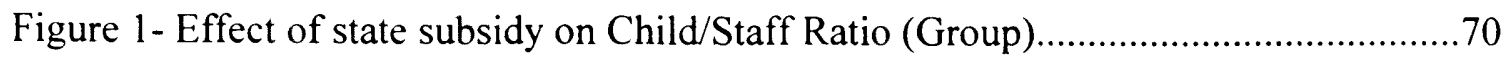

Figure 2- Interaction of state subsidy and maximum group size ................................

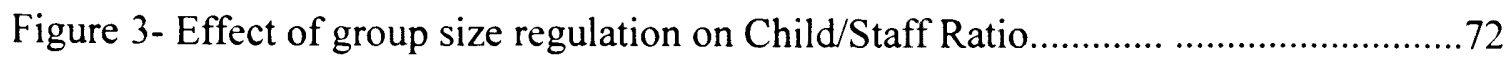

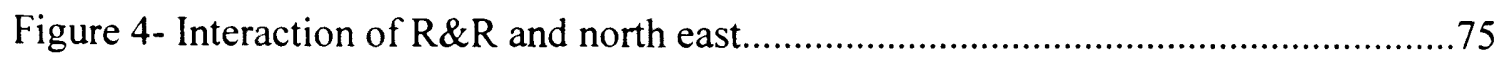

Figure 5- Interaction between public school sponsor and rural area..............................76

Figure 6- Interaction between church sponsor and rural area......................................77

Figure 7-Interaction between public school sponsor and central city............................79

Figure 8- Interaction of R\&R and maximum group size on Child/Staff Ratio................80

Figure 9- Effect of child/staff regulation (37-60) months on Child/Staff Ratio

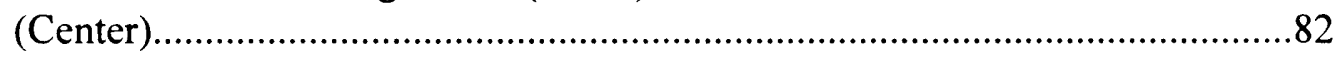

Figure 10- Effect of group size regulation (25-36) months on Child/Staff Ratio...............84

Figure 11-Effect of group size regulation (0-12) months on Child/Staff Ratio.................86

Figure 12-Interaction between maximum group size regulation and rural........................87

Figure 13-Effect of group size regulation (37-60) months on Hourly Fee.........................90

Figure 14-Effect of child/staff regulation (0-12 mths) on Hourly Fee...........................

Figure 15-Interaction of R\&R agencies and child staff regulation................................92

Figure 16-Interaction of prekindergarten funds and group size regulation......................94

Figure 17-Interaction of SSBG subsidy and group size regulation..................................95 


\section{CHAPTER ONE}

\section{ISSUES AND OBJECTIVES}

From the Great Depression when the first federal program to subsidize children was started to the 101 st Congress in 1990, and to the recently signed welfare law titled "Personal Responsibility and Work Opportunity Reconciliation Act of 1996" child care for low-income families has been given a high priority by the federal government. There are two reasons behind these child care subsidies. First, to promote economic selfsufficiency among poor families so that they no longer remain a burden to the public and second, to prevent future burden to the society by promoting the health and development of poor children (Hofferth, 1993).

\section{Economic Self-sufficiency}

The goal of welfare has changed from supporting poor women to stay at home, to providing them with employment or employment training. The passage of the Family Support Act of 1988 and the Personal Responsibility and Work Opportunity Reconciliation Act of 1996 are a testimony to this. Under the Family Support Act of 1988 , the focus is on preparing mothers with children age three and older for selfsufficiency through employment in a job training and education program appropriately called "JOBS" (Job Opportunity and Basic Skills). More recently, economic selfsufficiency has been given a high priority by the Personal Responsibility and Work Opportunity Reconciliation Act of 1996. Under this Act, the work participation rate for welfare recipients increases from 25 percent in fiscal year 1997 to 50 percent in fiscal 
year 2002. Also Block grant funds under the new welfare law cannot be used for adults who have received welfare for more than five years (Katz, 1996).

\section{Health and Development of Poor Children}

There is clear evidence that preschool education is beneficial for the cognitive and social development of poor children. Several studies have indicated that disadvantaged children benefit most from quality intervention programs (Burchinal, Lee, and Ramey, 1989; McCartney, Scarr, Phillips, and Grajek, 1985; Lee, Brooks-Gunn, Schnur, and Liaw, 1990; Lee, Schnur, and Brooks-Gunn, 1988; Darlington, Royce, Snipper, and Lazar, 1980).

These two issues -- economic self-sufficiency and health and development of poor children-- were the guiding force of the 101 st Congress in 1990 (Hofferth, 1993). The 1990 Legislation, which greatly expanded the child care subsidies, contained components ranging from providing tax credits to working poor families to expansion of funding for Head Start -- the federal program whose goals are to improve the social skills, learning ability, and health and nutrition status of low-income children so that they can begin school on an equal footing with their more economically advantaged peers (Hofferth, 1993; Committee on Ways and Means, U.S. House of Representatives, 1991). Little research has been done on the effect of these subsidies. Till now, efforts have been concentrated on the effects of Dependent Child Care Tax Credit (Robins, 1990; Garfinkel, Meyer, and Wong, 1990). To partially fill in this gap, this study examines the effect of subsidies on price and quality of child care for low-income families. 
Child Care Providers for Low-Income Children

For background, the child care market for low income families is briefly described here. The child care market has four participants -- parents whose children need care, children who need care, providers who provide care and government whose role influences use of child care arrangements through subsidies and regulations. Child care providers can fall into any one of the following categories -- relatives caring in their own home or in child's home, whether paid or unpaid; babysitter providing care in the child's home; center - based care which provides care in a child care center away from the child' home and family day care provider who is a nonrelative providing care in the provider's own home.

This research assumes importance due to the following issues:

--- In light of the goal of welfare reform to promote self-sufficiency among welfare recipients, the demand for child care among low-income families will increase substantially.

-.- The spending by the federal and state governments under the four child care programs for low-income families (Family Support Act of 1988, Transitional Child Care (TCC), At-Risk Child Care Program and Child Care and Development Block Grant program of 1990), was $\$ 1.5$ billion in fiscal year 1992 (General Accounting Office, [GAO], 1994). It is important that we know the effect of these subsidies on price and quality of care, due to the huge financial outlay involved. 
--- Child care costs consumed as much as $27 \%$ of monthly income for families with incomes below poverty who paid for child care in 1991, compared with $7 \%$ for families with incomes above poverty (GAO, 1994).

-.- Child care subsidies also significantly affect the mother's decision to work. A GAO study (1994) "Child Care subsidies increase likelihood that low-income mothers will work" found that the impact of full subsidization of care will have the greatest effect on poor mothers when compared to near-poor and non-poor mothers.

The model predicts that providing a full subsidy to mothers who pay for child care could increase the proportion of poor mothers who work from $29 \%$ to $44 \%$, and that of near-poor mothers from $43 \%$ to $57 \%$ and non-poor mothers from $55 \%$ to $65 \%$.

--- Good quality child care according to The National Academy of Sciences Panel on Child Care Policy is affected by group size, staff-child ratios, care giver education and training and care giver stability and continuity ( Hayes, Palmer, and Zaslow, 1990). Phillips, Voran, Kisker, and Whitebook (1994) found that quality of care provided by child care centers serving a high proportion of low-income children varies and is sometimes inadequate in some of the key indices of quality.

This research will enable us to know if the current system of child care subsidies has the desired effect. If it is found that the effect of subsidies is negative on price and positive on quality of care then it can be concluded that child care subsidies have resulted in lowering the price of care and improving the quality of care. If it is found that the child care subsidies have a positive effect on price of care and a 
negative effect on quality, then it is obvious that the child care subsidies have an undesirable effect on both price and quality.

Chapter 11 will discuss literature review, chapter 111 will outline the conceptual framework, data will be discussed in chapter $1 \mathrm{~V}$, chapter $\mathrm{V}$ will describe the empirical model, chapter VI will discuss the empirical results and policy implications, and chapter VII will discuss summary and conclusions. 


\section{CHAPTER TWO \\ LITERATURE REVIEW \\ Low-income Child Care Market}

Low-income children are more likely to be cared for within the family. $48 \%$ of lowincome children under age 5 and children aged 5 to 12 years are taken care of mainly by their parents (i.e for the greatest amount of hours per week) (Brayfield, Deich, and Hofferth, 1993). Larner and Mitchell (1992) found that $60 \%$ of low-income children were cared for within the family as compared to $33 \%$ of high-income children. Also relatives play an important role in caring for low-income children. Brayfield, Deich, and Hofferth (1993) found that relatives were the main source of care for $22 \%$ of low income children under 5 years of age and $20 \%$ of low-income children aged 5 to 12 years. They also found that grandparents are a predominant source of relative care. Nearly $17 \%$ of all low-income children under age 5 were cared for mainly by a grandparent. Other studies have similar findings. Marshall and Marx (1991) found that 27\% of low-income children aged below 6 years and $60 \%$ of low-income children aged 6 to 12 years were cared for by relatives. Maynard (1990) found that 30 to $33 \%$ of preschool children in low-income areas were cared for by relatives. The importance of center care for low income children has mixed findings. Marshall and Marx (1991) found that full-time care is especially important for low-income children. $36 \%$ of low-income children younger than six who are in child care are in full-time center care. Maynard (1990) found that $20 \%$ of preschoolers from low-income areas are in center based care. According to Brayfield, 
Deich, and Hofferth (1993), 15\% of low-income children under 5 years and $6 \%$ of children aged 5 to 12 years used center based care. The findings on use of Family Day Care by low-income children ranges widely. Maynard (1990) found about $25 \%$ of preschool children in low-income areas are cared for by family day care centers. Marshall and Marx (1991) found that $18 \%$ of low-income children below 6 years of age and $6 \%$ of children aged 6 to 12 years are cared for by family day care providers. A much lower use of family day care providers was found by Brayfield, Deich, and Hofferth (1993). They found that $8 \%$ of low-income children aged under 5 years and $4 \%$ of children aged 5 to 12 years mainly used family day care providers.

To summarize, relatives especially grandparents play a significant role in the care of low-income children. Center based care also plays an important role in the care of lowincome preschoolers. With the recent emphasis on getting welfare recipients off welfare and into employment training the importance of center care has increased.

According to Robins (1991) the goals of a national child care policy are affordability, accessibility and quality. Keeping these goals in mind, the current literature on low-income child care will be surveyed. 


\section{Affordability of Child Care}

Price is one of the most important factors affecting parental choice of child care arrangement. If the price of a particular type of child care arrangement is higher, the probability of using that type of care is less (Hofferth and Wissoker, 1992;

Yeager, 1979). Spiegelman and Robins (1978) also found that demand for market form of child care (day care centers and licensed family day care centers) is price elastic. It was also found that welfare recipients who are often eligible for subsidized child care, are more likely than comparable women not receiving welfare to use paid care outside their home for younger preschoolers (Leibowitz, Waite, and Witsberger, 1988). It has been found that low-income families could afford to pay only $6-7 \%$ of their income for child care (Dubnoff, 1986 cited in Marshall and Marx, 1992). Brayfield, Deich, and Hofferth (1993) found that low-income families spend an average of $23 \%$ of their weekly gross family income for child care for children under 5 years. Other studies have also found high proportion of child care costs to income. Hofferth (1995) found that working-poor families spent $33 \%$ of their weekly household income on child care costs. Maynard (1990) found that low-income families spent an average of $20 \%$ of family income and $30 \%$ of the mother's income on child care.

High costs of child care has a negative effect on probability of labor force participation of women. Maynard (1990) found that $60 \%$ of the low-income mothers who were not already employed reported that they would work if adequate and affordable child care were available to them. Marshall and Marx (1991) report that lack of 
affordable, quality child care is a major problem faced by low-income families. They also found that nearly half of low-income women not employed now would look for a job or seek training if affordable, quality child care becomes available. The correlation coefficient between paying for care and participating in the labor market is -0.38 for married women (Connelly, 1992). The higher the cost, lesser the probability of participating in the labor market. High child care costs are also a greater barrier to women in poverty. Kimmel (1995) found that for the full poverty sample of single mothers, the price elasticity of employment is -0.346 , and for white and black single mothers in poverty the price elasticities are -1.362 and -0.345 respectively. Fronstin and Wissoker (1994) found that the estimated effects of price on employment were more negative in the low-income samples than in the high income samples. In a study by Blau and Robins (1989) it was found that higher child care costs are estimated to lower the birth rate for nonemployed women. They also found that higher child care costs also increase the rate of leaving employment and reduce the rate of entering employment.

Subsidies have a positive effect on the probability of employment by women. Connelly (1992) in her study of child-care costs on married women's labor force participation found that if child care costs were subsidized by $50 \%, 64 \%$ of married women with young children would be employed, and if there were universal no-cost child care available, $68.7 \%$ of women would be employed. Kimmel (1995) in her study of lowincome single mothers found that provision of free child care causes a $132 \%$ increase in the employment probability of white single mothers. She also found that the 
implementation of a sliding-scale increases employment of white single mothers by $105 \%$.

A 1994 GAO study found that subsidizing child care costs has the greatest impact on poor and near-poor mother's decision to work, as compared with nonpoor mothers. Full subsidization to mothers who pay for child care increases the proportion of poor mothers working from $29 \%$ to $44 \%$, and that of near-poor mothers from $43 \%$ to $57 \%$. The probability of nonpoor mothers working could increase from $55 \%$ to $65 \%$.

In short, higher child care costs influences the parental choices of care and has an impact on the probability of labor participation of women. Labor participation of women has assumed greater significance given the proposed changes in welfare.

Accessibility of care

Low-income working families face major constraints in finding accessible child care of good quality. For a welfare mother to use a child care arrangement for employment, it must be conveniently located, and be dependable (Sonenstein and Wolf, 1991). Also working poor families are more likely to be in part-time employment. Hofferth (1995) found that $45 \%$ of working-poor families worked full-time compared to three quarters of mothers in other families. Maynard (1990) found that proportionately more low-income parents work part-time ( two-thirds vs one-third of all working mothers). She also found that part-time employment tends to restrict child care choices to family day care. Hofferth (1995) reports that only 2 out of 3 centers operate full-time, compared with almost all family day care homes. Parents who need full-time care for their children have also to use 
more than one supplemental arrangement. Among low-income families, about $24 \%$ of children under age 5 are in more than one supplemental arrangement on a regular basis (Brayfield, Deich, and Hofferth, 1993). Also low-income working mothers need care at odd hours ( between 6 P.M. and 7 A. M.) and weekends (Sonenstein and Wolf, 1991). Centers seldom provide such extended hours care (Larner and Mitchell, 1992). Hofferth (1995) found that one-third of working-poor and more than one out of four working-class mothers work weekends. Only $10 \%$ of centers and $6 \%$ of family day care homes provided care on weekends. Also $13 \%$ of regulated and $20 \%$ of nonregulated family day care providers provided care in the evenings, compared to only $3 \%$ of centers .

Centers seldom provide care for sick children when compared to family day care providers. Sonenstein and Wolf (1991) in their study of 382 AFDC mothers found that during the preceding eight months, the welfare mothers whose children were with relatives or in family day care settings had missed one day of work to be with sick child, while mothers using center care reported missed six days.

Low-income parents find it difficult to use center-based care because they are more vulnerable to lay off (Larner and Mitchell, 1992). Lack of reliable public transportation inhibits the use of quality child care arrangements by low-income families. Low-income families tend to live in low-income neighborhoods that are poorly maintained, lack public transportation and community services (Larner and Mitchell, 1992). Duncan and Hill (1977) found that locational characteristics were the most important determinants of the choice of nursery school and day care facilities. Increasing 
the travel time from home to the place of child care arrangement reduces the likelihood of using that arrangement by a small but significant amount (Yeager, 1979).

\section{Quality of care}

The first wave of studies asked whether participation in a family day care or day care center was harmful to children. Once it was concluded with some certainty from research findings that child care participation was not harmful to children's development (Hayes, Palmer, and Zaslow, 1990), the second wave of research came into existence. The second wave of child care research, still in progress according to Zaslow ( 1991) examines children's development in light of variations in the environment of child care. According to Zaslow (1991) research uses one or all the following three approaches to measuring quality. The first approach, global or summary measures (e.g. high, medium, or low) is based on composite picture of such factors as staff/child ratios, caregiver training, organization of space, and daily routine. The second approach focuses on structural measures (e.g. group size, staff/child ratio, care-giver qualifications, care giver training). The third approach focuses on interactive behavior, particularly of care givers with children (e.g. care-giver involvement, frequency of care-giver talk to children). The outcomes measured under these approaches are the child's experiences in day care, child's socioemotional and cognitive development.

Today a balanced approach prevails emphasizing the social skills and cognitive development of the child (Mukerjee and Witte, 1992). The National Academy of Sciences panel on Child care policy in its description of characteristics associated with children's 
development, emphasizes both emotional and social development of children. The characteristics are:

i) Group size, staff-child ratios and care giver qualifications (called the iron triangle);

ii) Care giver stability and continuity, which is important for the development of secure attachments for the child;

iii) The structure and content of daily activities, which aid cognitive development, and

iv) Space and facilities e.g. the age-appropriateness of the activity areas which influence social interactions and development (Hayes, Palmer, and Zaslow, 1990 as cited in Kisker and Maynard, 1991).

Quality of child care services should be treated as multidimensional instead of unidimensional in nature. Preston (1993) controls for vector of quality and social externalities to compare production functions of profit and non-profit sectors. The vector of quality attributes include proxies for labor quality: maximum salary paid, turnover rate of care givers, child-to-staff ratio, parental participation in fundraising; staff selection; budget review and care giving. Hagey (1992) develops a model of child care choice that incorporates quality as a multidimensional concept. In this model consumers purchase a vector of attributes of care rather than a level of child care quality. The consumers then trade off these attributes of care in their choice of child care arrangement. The vector of attributes include child-to-staff ratio, group size, provider training, proximity, and 
extended hours of care for each child care arrangement.

Zaslow (1991) found that in child care of higher overall quality and in care which is higher in quality in terms of specific structural features, children experience a warmer emotional climate and more frequent personal interactions with care givers. Phillips, Scarr, and McCartney (1987) found that both parents and care givers in centers with higher amounts of adult child verbal interactions rated the children as more considerate, and care givers also rated them as more sociable, intelligent, and task oriented.

Child-staff ratios got mixed ratings. The effect of child-staff ratios on social development got predicted parents rating of considerateness and caregiver rating of anxiety (Phillips et al., 1987). Sonenstein and Wolfe (1991) found that a predictor of satisfaction for mothers of children aged below 3 years and 3 to 5 years was the level of adult supervision. For children below 3 years old lower child-staff ratio was associated with higher level of satisfaction.

Arnett (1989) in his study of 22 day-care centers on the island of Bermuda found that training was found to be related to less authoritarian child rearing attitudes and to a more positive interaction style with children, with less punitiveness and detachment. Whitebook, Howes, and Phillips (1989) in its study of 227 child care centers in five metropolitan areas in the U.S. found that the quality of care provided by most centers was rated as barely adequate. Better quality centers had higher wages, better work environments, lower teaching staff turnover, better educated and trained staff and low child staff ratio. Children attending lower-quality centers and centers with high staff 
turnover were less competent in language and social development. Whitebook et al. (1989) found that formal education obtained by a teacher was a strong predictor of appropriate teacher behavior and specialized training was important in infant classrooms.

Numerous studies have dealt with the effect of quality intervention programs on social and cognitive development for socioeconomically disadvantaged children. Burchinal, Lee, and Ramey (1989) found that quality day care positively affects the overall preschool cognitive level of socioeconomically disadvantaged children. McCartney et al. (1985) found that disadvantaged children attending high-quality government day care intervention program have better language skills, are more considerate and more sociable than children attending other lower quality day care programs. Research findings on follow up study of Head Start through grade 1, of 646 disadvantaged black children found that, on some measures of cognitive and analytical ability children who participated in Head Start maintained substantive gains especially when compared to children with no preschool (Lee et al., 1990). A one year follow up study of disadvantaged children attending Head Start found that participation in Head Start appeared to produce substantive 1-year gains on measures of cognitive ability for low-income children. This advantage was clearer when compared to no preschool group (Lee et al., 1988).

Whitebook et al. (1989) found that low and high-income children were more likely than middle-income children to attend centers providing higher quality of care. 
Phillips et al (1994) concluded in their study of 32 low-income centers, that quality of care provided in low-income and middle income centers is highly variable. Centers catering to upper-income children provided the highest quality of care. Berger and Black (1992) found that subsidies increase parental satisfaction of quality of care. A part of child care literature is concerned with the modal choice of child care arrangements. Leibowitz, Waite, and Witsberger (1988) found that parents did not pay more for care that met recommended group size levels or recommended staff/child ratios. They also found that highly educated women or women with higher income did not obtain quality care . Staff-child ratio which is an indicator of quality is a factor in decision of type of care, but not for all types of care arrangements (Hofferth and Wissoker 1992). The higher the mother's wage greater is the probability of selecting center-based facility (Hofferth and Wissoker 1992; Lehrer 1983; Spiegelman and Robins 1978; Duncan and Hill, 1977). Brayfield and Hofferth (1995) found that higher the mother's earnings and higher the family income from other sources, employed mothers allocated more money to child care and the proportion of child care expenditures to overall family budget was smaller.

While Hofferth and Wissoker ( 1992) found that family income affected the modal choice of care, Spiegelman and Robins ( 1978) and Duncan and Hill (1975) did not find family income statistically significant in determining the modal choice of care. The findings of the effect of husband's income is also mixed. While (Lehrer, 1983) found husband's income determined modal choice of care, (Leibowitz, Waite and Witsberger, 1988) found no effect of husband's income on type of care. Mother's hours of work 
determines the modal choice of care (Lehrer, 1983). The lower the level of the mother's labor supply, the more likely it is that dependence will be placed upon relatives rather than upon baby-sitters or day-care centers, and, comparing the latter two modes, the lower the likelihood of dependence on center care. Education of the mother is an important determinant of type of care. Duncan and Hill (1975) found strong relationship between average education of parents and choice of nursery school and day care center form of care. Mothers who are college educated prefer to enroll their children in educationally based programs that require some form of payment (Brayfield and Hofferth, 1995). Leibowitz, Waite, and Witsberger (1988) found that mother's education affects the chances that the mother will choose age-appropriate care--care in child's home for younger preschoolers and center care for older preschoolers.

The age of child bears a strong relationship to mode of care arrangement. Presence of children aged $0-3$ increases the odds of choosing a baby sitter over day care center. The presence of children in the 3 - 6 years increases the odds in favor of nursery schools or day care centers over relatives (Lehrer, 1983; Duncan and Hill, 1975). As the number of children increases, it becomes more likely that reliance will be placed on a relative or babysitter instead of day care center (Lehrer, 1983; Duncan and Hill, 1975). When there is a teenager in the household, relatives are the preferred child care arrangement (Lehrer, 1983). Residence in the South and West increases the odds in favor of day care center (Lehrer, 1983; Duncan and Hill 1975). Leibowitz, Waite and Witsberger, 1988 found that group care for preschool children (day care or nursery school) is significantly higher in 
the South. City size also influences the choice of mode of care. Families living in the largest cities were generally more likely to choose day care centers and nursery schools than were families living in smaller cities and towns (Duncan and Hill, 1977, 1975).

Religion has a limited effect on choice of mode of care. Lehrer (1983) and Duncan and Hill (1975) found affiliation with the Catholic Church has a negative impact on choice of day care facilities. Duncan and Hill (1975) found that Baptists are more likely to choose the formal mode of care. Race has no impact on choice of mode of care (Lehrer, 1983; Duncan and Hill, 1975).

\section{Child Care Subsidies}

Both federal and state programs provide child care assistance to low-income families. 


\section{Federal Programs}

The major federal programs providing child care subsidies are as follows:

Family Support Act of 1988 (FSA) FSA which seeks to promote economic selfsufficiency of welfare recipients, guarantees child care to employed Aid to Families with Dependent Children (AFDC) recipients and to participants in the Job Opportunities and Basic Skills Training (JOBS) program, as well as other AFDC recipients in state approved education and training (GAO, 1994). Those parents on AFDC who have children age three and older can be required to participate in the JOBS program; those with children as young as age one may be included at the option of the state. Also, FSA created the Transitional Child Care (TCC) program, which guarantees a year of transitional child care to AFDC recipients after they leave the welfare rolls due to increased income.

Primary responsibility for JOBS rests with each state's welfare agency. The federal legislation requires states to provide these JOBS services to 7 percent in 1990 of the non-exempt caseload. The participation rate increases to $20 \%$ in 1995 . (Hagen and Lurie, 1992). Federal funds under this program are provided to states to fund child care entitlement.

At-Risk Child Care Program The At-Risk Child Care Program was part of the Omnibus Reconciliation Act of 1990 (OBRA 90). The Act increased funding for the existing AFDC child care program to provide child care services to low-income, non-AFDC families would be at risk of becoming eligible for AFDC. State matching funds 
are required to draw federal funds. Federal funds available under this program is up to $\$ 300$ million dollars for each of the fiscal years 1992, 1993 and 1994 (Poersch, Adams, and Sandfort, 1994).

Child Care and Development Block Grant (CCDBG) The CCDBG was enacted under the Omnibus Reconciliation Act of 1990 (OBRA 90). This program provides Federal funds to States, Tribes, and Territories to support child care services for low-income families, especially children of families with very low family income and to children with special needs.

The CCDBG is funded at $\$ 750$ million in fiscal year 1991, $\$ 825$ million in 1992 , $\$ 892.7$ million in 1993 and 892.7 million in 1994 (Morse and Steisel 1990; Poersch, Adams, and Sandfort, 1994).

Head Start Head Start began operating in 1965 under the general authority of the Economic Opportunity Act of 1964. Head Start provides a wide range of services to primarily low-income children, ages $0-5$, and their families. Its goals are to improve the social competence, learning ability, health and nutrition status of low-income children so that they can begin school on an equal footing with their more economically advantaged peers (Committee on Ways and Means, U.S. House of Representatives, 1991)

Head Start was reauthorized by Congress in the Head Start Expansion and Improvement Act of 1990. This important legislation authorized sufficient funding to serve all eligible children by 1994 and contained provisions to improve quality. Congress increased Head Start funding by $\$ 399.8$ million in Fiscal Year 1991. Under the provisions 
of the Act, $\$ 195.2$ million of this increase was set aside for quality improvements; $\$ 200$ million was available for expansion; $\$ 10$ million was reserved for Training and Technical Assistance (T\&TA) (National Head Start Association, 1993). Head Start programs normally operate part-day for part of the year (Hofferth, 1993).

The two other major Head Start legislations are 1) The Head Start Improvement Act of 1992 which among several additional changes it made to the Head Start programs guaranteed quality improvement funds to all 1993 grantees and 2) The Human Services Reauthorization Act of 1994 which reauthorizes the Head Start program through 1998. The 1994 legislation specifies that $25 \%$ of new funds must be reserved for quality improvement activities (DeWoody, CWLA, 1994)

Title XX : The Social Services Block Grant In 1974, Congress created a new title XX of the Social Security Act under Public law 92-672 authorizing an entitlement for states for providing social services (Committee on Ways and Means, U.S. House of Representatives, 1991). Many states use some of these funds for the purpose of providing child care subsidies ( Poersch, Adams, and Sandfort, 1994).

The Omnibus Budget Reconciliation Act of 1981 (Public Law 97-35) amended title XX of the Social Security Act to establish a "Block Grant to States for Social Services" (Committee on Ways and Means, U.S. House of Representatives, 1991). Over the years there has been a substantial reduction in Title XX purchasing power. In FiscaI Year 1993, \$2.8 billion was appropriated for the Title XX Social Services Block Grant ( Poersch, Adams, and Sandfort, 1994). 
Dependent Care Tax Credit Under section 21 of the Internal Revenue Code, a nonrefundable credit against income tax liability is available for up to 30 percent of a limited amount of employment-related dependent care expenses. Eligible employmentrelated expenses are limited to $\$ 2400$, if there is one qualifying individual, or $\$ 4,800$, if there are two or more qualifying individuals. The maximum amount of the credit is $\$ 720$ for one qualifying individual and $\$ 1,440$ for two or more qualifying individuals.

Because of lack of variation, the federal dependent credit was not included as a subsidy in the study. Many states also reimburse parents for child care expenses. Twentythree states (including the District of Columbia) had Child and Dependent Care income tax provisions in tax year 1993 (Steinschneider, Campbell, and Williams, 1994). These provisions may be credits or deductions. Credits reduce the state tax liability. Deductions reduce the amount of income subject to the state tax and thus reduce the amount of state tax owed. The state tax credits varied across states and this was used as a measure of subsidy for this study.

\section{$\underline{\text { State Programs }}$}

States provide child care assistance either by subsidizing the cost of child care or by providing early childhood services to a children from low-income families.

Funding for these programs is provided out of state funds or drawn out of federal child care programs. State child care programs can be grouped into the following categories (Adams and Sandfort, 1994): 
Economic Self-Sufficiency Child care assistance is offered to low-income parents who are working or in training programs. Child care funds for welfare recipients are administered through states Job Opportunities and Basic Skills (JOBS) programs (Adams and Sandfort, 1994).

Prekindergarten Programs Prekindergarten Programs for this study are those state-funded initiatives that provide at least some education-related services to prekindergarten age children (Adams and Sandfort, 1994). By the year 1991-92 school year, 32 states were investing a total of about $\$ 665$ million in these Prekindergarten programs providing services to almost 290,000 children (Adams and Sandfort, 1994). State-funded Prekindergarten initiatives were aimed mainly at low income four year old children. The definition of low-income children varies among states. Some states defines lowincome child as children whose families were eligible for AFDC assistance or whose family income was below a certain specified state level or both. Besides income other criteria include children with disabilities, children whose primary language was other than English, children in families with a history of school failure or illiteracy, children of teen parents or migrant families, abused or neglected or drug-exposed infants or children who lived in families with a history of substance abuse or who lived in inadequate housing (Adams and Sandfort, 1994, pp. 51-53).

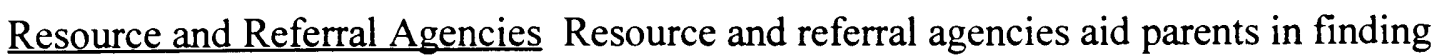
suitable child care facilities. These agencies help parents identify child care location, fees and availability of child care facilities. The role of resource and referral agencies is 
limited because they lack legal authority and staff capacity to offer judgements on the adequacy of care (Meyers, 1995). 


\section{CHAPTER THREE}

\section{CONCEPTUAL FRAMEWORK}

The first step in developing the conceptual framework is sketching out the structural equation. The structural equation helps us understand the underlying behavior of individuals and firms making a decision. By using structural equations we can understand the behavior of low-income families who are the demanders of child care, making decisions about the purchase of child care. Structural equations help us also understand the behavior of providers who are the suppliers of child care, making decisions about the supply of child care. On the demand side, families make decisions whether to purchase child care in the market and if so what type of child care. Structural equations help us understand the factors behind these decisions.

Structural equations also help us specify a second set of relationships called reduced-form equations. Reduced-form equation contains endogenous variables on the left-hand side and exogenous variables on the right-hand side. Endogenous variables are those whose values are determined within the model under study. For e.g, price of care is endogenous. Exogenous variables are those whose values are determined outside the model or predetermined. For e.g., exogenous variables include rules for administration of subsidy, community characteristics and child care regulations.

Building on the earlier models describing how families choose to care for their children (Chipty and Witte, 1994) the following structural equations are developed. The 
first structural equation is the decision by a low income family is whether to have family or non family child care. A number of factors influence this decision. It may include family characteristics (education of the mother, family income, mother's wages, number of children in the family), care characteristics ( quality of care, education and training of the provider), wages and hours of work of family member if they choose to care within family or use nonfamily care, price of family care and nonfamily care ( net of subsidies), Community characteristics (accessibility and outreach methods used by subsidy programs in the community, size of community) and availability of subsidies (sliding scale fee, vouchers, Child Care Dependent Tax Credit, Head Start). Family/Nonfamily $=\mathrm{d}\left(\right.$ FAMCHAR, CARECHAR, CARECHAR $_{\mathrm{nf}}, \ldots$, CARECHAR $_{\mathrm{nf} j}$, WAGES $_{\mathrm{f}}$, HOURS $_{\mathrm{f}}$, WAGES $_{1}, \ldots$, WAGES $_{\mathrm{j}}, \ldots$, HOUR $_{1}, \ldots, \mathrm{HOUR}_{\mathrm{j}}$,

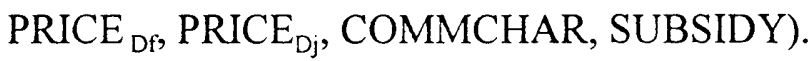

Famchar is the family characteristics (education of the mother, race, number of children under the age of 13); CARECHAR is the characteristics of family care, CARECHAR $_{\mathrm{nf}}, \ldots, \mathrm{CARECHAR}_{\mathrm{nf}}$, is the characteristics of nonfamily care arrangements from 1 to $J$ types (education and training of the provider, staff-child ratio); the wages and hours of work of family members responsible for child care if these individuals choose to care for their children within the family, denoted WAGES and HOURS $;$; and the wages and hours available if these family members choose one of the J nonfamily care arrangements, denoted WAGES $1, \ldots$, WAGES $_{j} ;$ HOURS $_{1}, \ldots$, HOURS $_{j}$; the prices of family care, denoted PRICE $E_{D f}$; and prices of nonfamily child care, denoted PRICE $E_{D 1} . . P R I C E_{D j}$ 
(net of subsidies) for the J types of nonfamily child care available and the characteristics of the community (COMMCHAR), and subsidies available (SUBSIDY).

The estimation of the reduced form of the above structural equation will give us the effect of subsidies on the choice of care. For e.g, we can discern the effect of availability of Head Start funding on the choice of care.

\section{Choice of the Type of Nonfamily Care}

Once of the family has decided on nonfamily care for its children, it is faced with a second decision--the type of nonfamily care to utilize. Nonfamily care refers to all care by providers other than members of the immediate family, including relatives outside the immediate household and family day care providers. The type of care decision is influenced by subsidy programs available (program budgets, rules, eligibility and outreach methods) denoted SUBSIDY, Characteristics of care from nonfamily types 1 to $\mathrm{J}$ denoted CARECHAR $1, \ldots$, CARECHAR $_{j}$; Prices (net of subsidies) denoted PRICED $_{1} \ldots$ PRICED for the $\mathrm{J}$ types of nonfamily child care available, the work schedules and wages of working family members, particularly the primary care giver (denoted WAGES $_{1}, \ldots$, WAGES $_{\mathrm{j}} ;$ HOURS $_{1}, \ldots$ HOURS $_{\mathrm{j}}$ ); community characteristics (COMMCHAR) and Family characteristics such as income (FAMCHAR).

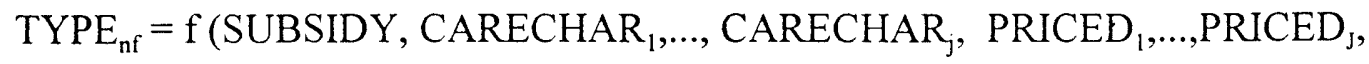

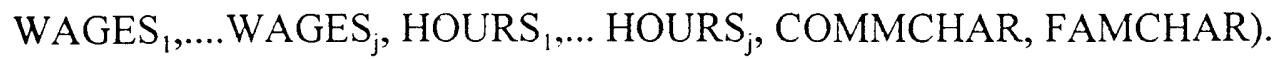

Estimating the reduced form of the above structural equation gives us the effect of program rules for administration of subsidies on the choice 
of type of care.

\section{Demand and Supply of Child Care}

The next two structural equations deal with demand and supply of child care. Equilibrium is determined by the interaction of demand and supply. Demand for any given type of care is determined by (1) the price of that type of care, net of any subsidies received directly by the parents (denoted Price ${ }_{d}$ ); (2) the work schedules of family members (hours ${ }_{w}$ ); (3) family characteristics (denoted famchar including family income adjusted for child care expenditures); (4) the characteristics of the children in the family (denoted childchar); (5) and community characteristics related to this type of child care in the local community (denoted Commchar ${ }_{d}$ ) (6) care characteristics (denoted Carechar ${ }_{1}$ ) and (7) subsidies.

$D_{n f}=f 1$ (Price $_{d}$, Hours $_{w}$, Famchar, Childchar, Commchar ${ }_{d}$, Carechar ${ }_{i}$, Subsidies).

Supply of care $\left(\mathrm{S}_{\mathrm{nf}}\right)$ depends upon (1) the price received for that type of care (Prices $)_{s}$ ) by providers, that is, the sum of parental payments and subsidy payments by governmental and nongovernmental agencies, (2) Subsidies, (3) Costs of labor and other inputs $\left(\mathrm{P}_{\mathrm{f}}\right),(4)$ the characteristics of the child to be cared for (childchar), (5) the characteristics of care provided $\left(\right.$ carechar $\left._{i}\right),(6)$ community characteristics related to child care supply $\left(\mathrm{Commchar}_{\mathrm{s}}\right),(7)$ nature and administration of regulation in the community (Regs) and (8) characteristics of provider (provchar). $S_{n f}=f_{2}\left(\right.$ Prices $_{s}$, subsidies, $P_{f}$, childchar, carechar ${ }_{i}$, commchar ${ }_{s}$, regs, provchar) The interplay of demand and supply will determine the market price and quantity of 
child care available for each type of care for unsubsidized families.

\section{Hedonic Price Equation}

Economists have developed a model called the hedonic model which estimates the implicit prices for the characteristics of care. To determine the implicit market price of each of the characteristics of care, the hedonic model begins with the equilibrium market price for care which is determined by the interplay of supply and demand.

The model gives an equation, called the hedonic price equation, that relates this equilibrium price to the characteristics of care,

$$
\mathrm{Pd}_{\mathrm{j}}=\mathrm{g}(\text { Carechar })
$$

This hedonic price equation allows us to uncover the market's implicit valuation of the characteristics of care. These valuations are the partial derivatives of the hedonic price function with respect to each characteristic of care. For each characteristic of care, there will be a distinct implicit price. The vector of implicit prices is denoted by $\mathrm{P}_{\text {carechar }}$.

The implicit prices for the attributes of care are used as explanatory variables in the demand equations. Family characteristics, child characteristics, provider characteristics and regulations including implicit prices affect the demand and supply of characteristics of care.

Carechar $_{i}{ }^{\mathrm{N}}=\mathrm{h} 1\left(\mathrm{P}_{\text {carechari, }}\right.$ famchar, childchar $)$

Carechari $^{\mathrm{S}}=\mathrm{h} 2\left(\mathrm{P}_{\text {carechari }}\right.$, Regs, childchar, Provchar $)$. 
Famchar is a vector of family characteristics, childchar is a vector of child characteristics, provchar is a vector of provider characteristics, regs is a set of regulatory variables affecting this characteristic of care, $\mathrm{P}_{\text {carechari }}$ is the implicit price for this characteristic of care.

\section{Reduced form equations}

Reduced form equations enable us to discern the net effect of exogenous variables on the endogenous variables. The exogenous variables are vector of attributes relating to family characteristics, child characteristics, regulations, subsidy, community characteristics, and the prices of inputs. Reduced form equations help us find the effect of each of the exogenous variables on each of the endogenous variables. For examples we can find the effect of subsidies on the price and quality of care. The reduced form equations will be estimated for price of care and quality indicated by (staff-child ratio at the center as well as the group level).

Staff-child ratio $=f 3$ (Famchar, Provchar, regs, childchar, subsidy, commchar, $\left.\mathrm{P}_{\mathrm{f}}\right)$ (Group Level)

Staff-child ratio $=f 2\left(\right.$ Famchar, Provchar, regs, childchar, subsidy, commchar, $\left.\mathrm{P}_{\mathrm{f}}\right)$ (Center Level)

Price of care $=f 1\left(\right.$ Famchar, Provchar, regs, childchar, subsidy, commchar, $\left.\mathrm{P}_{\mathrm{f}}\right)$ 


\section{CHAPTER FOUR}

\section{DATA}

The 1990 Profile of Child Care Settings (PCCS) data contains a nationally representative sample of early education and care providers drawn from the universe of formal early education and care programs. Kisker et al (1991) provide a detailed description of the PCCS data. The sample was selected in two stages. In the first stage, a stratified sample of 100 counties that are representative of counties in the U.S. were selected. Counties were stratified according to region, metropolitan status, and poverty level, and sample counties were selected which had a probability proportional to the size of the population under age 5 . The 100 counties became the 100 PSU's.

In the second stage of the sampling, a stratified random sample of early education and care providers were selected from the 100 PSU's initially selected. In order to draw the provider sample, a sample frame list of eligible providers stratified according to whether they were home based programs, head start programs, public-school based programs, or other center based programs was assembled. Random samples of programs were then drawn from each stratum. Interviews were conducted from October 1989 to February 1990 using computer assisted telephone interviewing methods. A total sample of 2,089 center based programs were interviewed.

The PCCS data permits in depth analysis of child care settings. For child care centers, the PCCS collected detailed information up to 20 child care groups and up to 10 
pricing arrangements for each center. The PCCS data also collected detailed information on subsidies received by providers and families.

The other major data source for demographics is the five-digit zip-code file of the 1990 U.S. Population Census. The zip-code files contained the center identification numbers which made it possible to match the centers and Zip-codes where each center was located. Where it was not possible to obtain five-digit zipcode demographic data, the 1990 Census of Population and Housing was used. The 1990 Census of Population and Housing gives demographic data pertaining to the county where each center is located. The other data sources used in the study are as follows: 
Table 1

Data Source

\begin{tabular}{|l|l|}
\hline \multicolumn{1}{|c|}{ Data } & \multicolumn{1}{c|}{ Source } \\
\hline Cost of Living Index for Urban Areas & $\begin{array}{l}\text { American Chamber of Commerce Researchers } \\
\text { Association, 1991, 2 nd quarter }\end{array}$ \\
\hline Community Characteristics & $\begin{array}{l}\text { US Federal Bureau of Investigation, } \\
\text { unpublished data, 1991 } \\
\text { 1.Crime }\end{array}$ \\
$\begin{array}{l}\text { US Bureau of Labor Statistics, Employment and } \\
\text { Unemployment for State and Local Areas, fiche, } \\
\text { annual, 1991 } \\
\text { 3. Direct General Expenditure } \\
\text { U.S. Bureau of the Census, 1982 and 1987 } \\
\text { Census of Governments, Government Finances, } \\
\text { Compendium of Government } \\
\text { Finances, (GC82(4)-5 and GC87(4)-5). }\end{array}$ \\
\hline$\frac{\text { Regulations }}{\text { State and local regulations }}$ & $\begin{array}{l}\text { Morgan, G. (1989). State liability insurance } \\
\text { requirements and regulatory information } \\
\text { (Table 3). Massachusetts: Work/Family } \\
\text { Directions, Inc. } \\
\text { U.S. General Accounting Office (GAO) (1992). } \\
\text { States face difficulties enforcing standards and } \\
\text { promoting quality child care. } \\
\text { Washington, DC: General Accounting Office } \\
\text { (March 1991 to May 1992). }\end{array}$ \\
\hline $\begin{array}{l}\text { Contract Rent per room } \\
\text { 1990 Census of Housing }\end{array}$ \\
\hline
\end{tabular}

(table continues) 
Data Source

\begin{tabular}{|c|c|}
\hline Data & Source \\
\hline \multicolumn{2}{|l|}{ Subsidies } \\
\hline 1.JOBS Program & $\begin{array}{l}\text { Committee on Ways \& Means, U.S. House } \\
\text { of Representatives. (1991). } 1991 \text { Green } \\
\text { Book. Washington, DC: U.S. Government } \\
\text { Printing Office. }\end{array}$ \\
\hline 2.Head Start Program & $\begin{array}{l}\text { U.S. Bureau of the Census (1994). } \\
\text { Consolidated federal funds report on } \\
\text { CD-ROM, fiscal year 1984-1993. }\end{array}$ \\
\hline 3.Pre-Kindergarten Program & $\begin{array}{l}\text { Mitchell, Seligson, and Marx, 1989; } \\
\text { Adams (1992). }\end{array}$ \\
\hline $\begin{array}{l}\text { 4.Title XX and State Subsidized Child } \\
\text { Care }\end{array}$ & Adams (1992) \\
\hline 5. Child and Dependent Care Tax Credit & Steinschneider (1994). \\
\hline 6. Resource and Referral (R\&R) Agencies & Curry (1996) \\
\hline
\end{tabular}




\section{CHAPTER FIVE}

\section{EMPIRICAL MODEL}

The next step in this study is to identify empirical measures for the endogenous as well as exogenous variables and to specify a functional form for the reduced form equations. Table 2 gives the definition of the dependent and independent variables suggested by the conceptual model. Table 3 contains a descriptive statistics of the dependent variables and explanatory variables.

This study seeks to estimate three reduced form equations. The dependent variable is the child staff ratio at the group level for the first reduced form equation, $(N=1939)$. Child-staff ratio at the group level is the ratio of total children over all groups to total teachers and assistant teachers over all groups for each center. The second reduced form equation is when the dependent variable is the child staff ratio for the center as a whole, $(\mathrm{N}=1808)$. Child-staff ratio is the ratio of total children to total teachers and assistant teachers for each center. The third reduced form equation that will be estimated is when the dependent variable is the weighted cost- adjusted average hourly fees charged by the child care centers, $(\mathrm{N}=1467)$. The PCCS survey obtained information of three different types of fee structures from each center. Programs that charge ten or fewer fees were asked about each fee, including the hours per day and days per week covered by the fee and the number of children for whom that fee was charged. Fees were converted into hourly fee rates. Then, the average fee was calculated by weighting each fee by the 
number of children for whom that fee was charged. Programs that charge more than ten fees were asked only about their highest, lowest and average fees. The average fee was recorded as it was given by the provider.

The empirical measures for the exogenous variables are as follows:

Subsidy The measures for subsidies include cost of living adjusted federal payments to states for child care under Job Opportunity and Basic Skills (JOBS) and Transitional Child Care (TCC) [under Title IV-A of the Social Security Act] per child aged 3-13 years in poverty, in the center's state; the cost of living adjusted federal Head Start dollars spent per child aged 0-5 years in poverty in the center's PSU area; the cost of living adjusted state and federal dollars for prekindergarten by state per child aged 3 to 4 years in poverty; the cost of living adjusted Title XX child care expenditure by state per child in poverty 0 to 13 years; cost of living adjusted state subsidized child care by state per child in poverty 0 to 13 years; a binary equal to 1 if the state has Child and Dependent Care Tax Provision available; cost of living adjusted maximum income tax deduction per family for child care for a maximum of two dependents.

Regulations Chipty (1995) and Chipty and Witte (1994) found that regulations have "spillover" effects. For example, regulations for centers have effects on family day care providers as well as centers. Based on their work, the following empirical measures were chosen for regulations: number of mandated inspections per year for center care; the inverse of the maximum group size permitted for each age group for center care and the maximum permitted child/staff ratio for each age group for centers. 
To find out the effects of resource and referral (R_R) agencies on child care markets, a binary equal to 1 if the center was located in a PSU area with an R\&R agency in 1990, was used as an empirical measure.

Family and community characteristics were controlled for in the areas where the center is located. Family and community characteristics control variables include cost of living adjusted median family income, percent families below poverty level, percent civilian unemployment, percent White, Black and Hispanic population and persons per household. Cost of living adjusted median hourly wage of teachers and median contract rent per room in the PSU areas where the center is located are the control variables for the cost of inputs. Median hourly wage of teachers was obtained from the 1990 PCCS data for each PSU area. Median contract rent per room for each PSU area was calculated from the 1990 Census of Housing data by dividing Median Contract Rent by the median number of rooms. The control variables for provider characteristics include whether the center is profit or non profit, whether sponsored by Head Start, public school or religious group and the number of months the center is in operation. 
Table 2

Dependent and Explanatory Variables

Dependent Variables

Theoretical

Constructs

Empirical Measures

Acronym

Source

Level

Price

Cost of living adj.weighted

cavgfees

PCCS

Center

Avg. hourly fee charged by ctrs

\begin{tabular}{|c|c|c|c|c|}
\hline \multirow{4}{*}{$\begin{array}{l}\text { Child-staff } \\
\text { ratio }\end{array}$} & Teacher, asst. teacher & Ch_tchr & PCCS & Center \\
\hline & $\begin{array}{l}\text { and child ratio } \\
\text { (center level) }\end{array}$ & & & \\
\hline & $\begin{array}{l}\text { Teacher, asst. teacher } \\
\text { and child ratio (group }\end{array}$ & Ch_tchrg & PCCS & Center \\
\hline & level) & & & \\
\hline
\end{tabular}

(table continues) 
Explanatory Variables

Theoretical

Constructs

Empirical Measures

Acronym

Source

Level

\begin{tabular}{|c|c|c|c|c|}
\hline \multicolumn{5}{|l|}{ Community } \\
\hline \multirow[t]{18}{*}{ Characteristics } & $\%$ movers from different & Migrant & 1990 Census of Pop. & County \\
\hline & State & & \& Housing & \\
\hline & Serious crimes per 100,000 & Crime & U.S. Bureau of & County \\
\hline & Resident Population, 1991 & & Investigation & \\
\hline & Travel time to work (in min.) & Travel & 1990 Census of Pop. & County \\
\hline & & & \& Housing & \\
\hline & Civilian unemployed as a & Unemp & U.S. Bureau of & County \\
\hline & percent of total civilian & & Labor Statistics & \\
\hline & Labor force, 1991 & & & \\
\hline & Direct General Expenditure & Pergenex & $1982 \& 1987$ Census & County \\
\hline & Per capita (Based on 1990 & & of Government. & \\
\hline & population) & & & \\
\hline & Persons per household & Hhsize & 1990 Census of Pop. & County \\
\hline & & & \& Housing & \\
\hline & Female civilian labor & Female & 1990 Census of Pop. & County \\
\hline & force as a $\%$ of civilian & & \& Housing. & \\
\hline & females 16 years or over. & & & \\
\hline & Percent White population & Perwhite & 1990 Pop. Census & Zipcode \\
\hline
\end{tabular}

(table continues) 
Theoretical

Constructs

Empirical Measures

Acronym

Source

Level

\begin{tabular}{|c|c|c|c|c|}
\hline & Percent Black population & PerBlack & 1990 Pop Census & Zipcode \\
\hline & Percent American Indians & PerAmInd & 1990 Pop Census & Zipcode \\
\hline & Percent Asians, Pacific Is & PerAsian & 1990 Pop Census & Zipcode \\
\hline & Percent Hispanics & Perhisp & 1990 Pop Census & Zipcode \\
\hline & Suppressed Other & & & \\
\hline & $\%$ in preschool (pvt \& public) & preschpr & 1990 Pop Census & Zipcode \\
\hline Family & $\%$ of children $<1$ year & Chld0per & 1990 Pop Census & Zipcode \\
\hline \multirow[t]{14}{*}{ Characteristics } & $\%$ of children $1-2$ years & Chld lper & 1990 Pop Census & Zipcode. \\
\hline & $\%$ of children $3-4$ years & Chld3per & 1990 Pop Census & Zipcode. \\
\hline & $\%$ of children 5 years & Chld5per & 1990 Pop Census & Zipcode. \\
\hline & $\%$ of children $0-5$ yrs & Chld05pr & 1990 Pop Census & Zipcode \\
\hline & $\% 65$ years \& older & Oldagepr & 1990 Pop Census & Zipcode. \\
\hline & Cost of living adj. Median & & & \\
\hline & Family Income & cmedinc & 1990 Pop Census & Zipcode \\
\hline & Cost of living adj. Median & & & \\
\hline & Family Income squared & cmedinc2 & 1990 Pop Census & Zipcode \\
\hline & $\%$ Female householder & Femper & 1990 Pop Census & Zipcode \\
\hline & $\%$ BA Degree or higher & BADegree & 1990 Pop Census & Zipcode \\
\hline & $\%$ No High School & NoHighpr & 1990 Pop Census & Zipcode \\
\hline & $\%$ receiving Public Assist & PerPublc & 1990 Pop Census & Zipcode \\
\hline & $\%$ families below poverty & Povper & 1990 Pop Census & Zipcode \\
\hline
\end{tabular}

(table continues) 
Theoretical

Constructs

Empirical Measures

Acronym

Source

Level

Regulations

Inverse Max grp size 0-12mo(cen) ingpsizl

Inverse Max grp size 13-24mo(cen) ingpsiz2

Inverse Max grp size25-36mo(cen) ingpsiz3

Inverse Max grp size 37-4yr(cen) ingpsiz4

Inverse Max grp size 5-12 yr (cen) ingpsiz12

Max ch/staff ratio 0-12mo(cen) chstf1

Max ch/staff ratio 13-24 mo(cen) chstf2

Max ch/staff ratio 25-36 mo(cen) chstf3

Max ch/staff ratio 37-4 yr (cen) chstf4

Number of mandated inspections visit

Cost of Inputs cost of liv adj. median

hrly wage of teachers in 1989-90

cost of liv adj. median contract cmedrent 1990 census of housing

stat/loc

Morgan, $1990 \quad$ stat/loc

Morgan, 1990

stat/loc

Morgan, 1990

stat/loc

Morgan, 1990

stat/loc

Morgan, 1990

stat/loc

Morgan, 1990

stat/loc

Morgan, 1990

stat/loc

Morgan, 1990

stat/loc

GAO. 1992

stat/loc

PSU

cmedhour PCCS

PSU rent per room in 1989. 
Theoretical

Constructs

Empirical Measures

Acronym

Source

Level

Provider

A binary $=1$ if sponsored by

Characteristics Head Start

Head

PCCS

Center

A binary $=1$ if sponsored by

public school

Pubsch

PCCS

Center

A binary $=1$ if sponsored by

religious group or church

Religous

PCCS

Center

A binary $=1$ if center is

nonprofit

Nonproft

PCCS

Center

A binary $=1$ if center is

forprofit

Forproft

PCCS

Center

Months the center is in

operation

Mthsopn

PCCS

Center

If center is located in Il, MI,

NE, MN, OH \& WI

Ncentral

PCCS

Center

If center is located in $\mathrm{AL}, \mathrm{FL}$

GA,KY,LA,NC,SC,TN,TX

South

PCCS

Center

If center is located in $\mathrm{CT}$,

MN,MD,NY,MA,NH,NJ,

PA,RI

Neast

PCCS

Center

(table continues) 
Theoretical

$\begin{array}{llll}\text { Constructs } & \text { Empirical Measures } & \text { Acronym } & \text { Source }\end{array}$

If center is located in $A Z$,

CA, CO, HI, ID,NM, OR,

WA, WY

West

PCCS

Center

If center is located in

the largest 20 counties

MSA

PCCS

Center

If center is located in

a non metropolitan area

Rural

PCCS

Center

If center is located in

a city whose population

is over 100,000

Cencity

PCCS

Center

(Suppressed category=

Other)

Subsidy Cost-adj. JOBS childcare $\$, 1990$

Per child 3-13 yrs in poverty

CJOBSper

Ways \& Means, 1991

State

Cost-adj. Headstart $\$, 1990$ per

Child $3-5$ yrs in poverty

CHeadper

Consol. Fed. Funds

PSU

Report, 1990

(table continues) 
Theoretical

Constructs

Cost-adj. Pre-K \$,1990 per

cPreK

Mitchel,Seligson,

State

child $3-4$ yrs in poverty

\& Marx, 1989;

Adams, 1994

Cost-adj. Title XX \$,1990

cSSBG

Adams, 1992

State

per child $0-13$ in poverty

(child care expenditure)

Cost-adj. State subsidized

CStatsub

Adams, 1992

State

child care per eligible

family/child 1990.

Cost-adj. Max deduction

Cmaxamt

Steinschneider, $\mathrm{J}$

State

for childcare for a max of

1994

2 dependents in

tax year 1993.

A binary $=1$ if the psu had a

R R

Child Care Research

$\mathrm{R} \& \mathrm{R}$ in 1990.

Partnership, 1996

PSU

A binary $=1$ if the state has

Child and Dependent Care

CADCProv Steinschneider,J State

Provision in Tax Credit in

1994

tax year 1993.

(table continues) 
Theoretical

Constructs

Empirical Measures

Acronym

Source

Level

A binary $=1$ if the State

Refund

Steinschneider,J

State

Child Care Dependent

1994

Credit is refundable

in tax year 1993.

Cost of living, 1991

Costliv

Cost of living index

Second Quarter,

Vol 24, No 2.

Produced by ACCRA. 
Table 3

Descriptive Statistics

Variable $\quad \mathrm{N}$ Mean Median $\begin{gathered}\text { Standard } \\ \text { Deviation }\end{gathered} \begin{gathered}\text { Coeff. } \\ \text { Variation }\end{gathered} \quad$ Skewness

Dependent

Variables

cavgfees

$1467 \quad 1.49 \quad 1.35$

0.82

0.55

2.07

Ch_tchr

$1808 \quad 10.68 \quad 9.00$

6.63

0.62

2.28

Ch_tchrg

$1939 \quad 8.47$

8.13

3.40

0.40

1.40

Explanatory

$\underline{\text { Variables }}$

Community

Characteristics

Migrant

$2088 \quad 0.10 \quad 0.08$

5.70

57.00

1.29

Crime

$2088 \quad 6059 \quad 5959$

2722

0.45

0.32

Travel

$2088 \quad 21.80 \quad 21.40$

3.76

0.17

0.08

Unemp

$\begin{array}{lll}2088 & 0.07 & 0.07\end{array}$

2.12

30.29

0.58

Hhsize

$2088 \quad 2.59 \quad 2.59$

0.19

0.07

$-0.56$

Female

$\begin{array}{lll}2088 & 0.58 & 0.58\end{array}$

5.73

9.88

$-0.22$

$\begin{array}{llll}\text { Perwhite } & 2046 & 0.76 & 0.88\end{array}$

0.27

0.36

$-1.33$

$\begin{array}{llll}\text { PerBlack } & 2046 & 0.17 & 0.04\end{array}$

0.26

1.53

1.77

PerAmlnd $\quad 2046 \quad 0.01 \quad 0.00$

0.03

3.86

18.60

$\begin{array}{llll}\text { PerAsian } & 2046 & 0.03 & 0.01\end{array}$

0.09

3.00

6.14

Perhisp

$\begin{array}{lll}2046 & 0.08 & 0.02\end{array}$

0.14

1.84

3.17

(table continues) 
Descriptive Statistics

\begin{tabular}{lllllll} 
Variable & $N$ & Mean & Median & $\begin{array}{l}\text { Standard } \\
\text { Deviation }\end{array}$ & $\begin{array}{l}\text { Coeff. } \\
\text { Variation }\end{array}$ & Skewness \\
\hline Preschpr & 2045 & 0.21 & 0.21 & 0.07 & 0.35 & 0.53 \\
Chld0per & 2045 & 0.15 & 0.15 & 0.04 & 0.27 & 0.84 \\
Chld1per & 2045 & 0.36 & 0.36 & 0.04 & 0.11 & -0.25 \\
Chld3per & 2045 & 0.33 & 0.33 & 0.04 & 0.12 & 0.96 \\
Chld5per & 2045 & 0.16 & 0.16 & 0.03 & 0.19 & 0.29 \\
Chld05per & 2046 & 0.09 & 0.09 & 0.02 & 0.22 & 0.53 \\
Oldagepr & 2046 & 0.13 & 0.13 & 0.05 & 0.38 & 0.58 \\
cmedinc & 2046 & 34752 & 32595 & 12596 & 0.36 & 1.45 \\
Femper & 2045 & 0.21 & 0.17 & 0.15 & 0.71 & 1.60 \\
BADegree & 2046 & 0.21 & 0.18 & 0.14 & 0.67 & 1.18 \\
NoHighpr & 2046 & 0.25 & 0.23 & 0.13 & 0.52 & 0.67 \\
PerPublc & 2045 & 0.08 & 0.06 & 0.07 & 0.88 & 2.35 \\
Povper & 2045 & 0.11 & 0.08 & 0.10 & 0.91 & 1.93 \\
Pergenex & 2089 & 1858 & 1523 & 2008 & 1.08 & 5.7
\end{tabular}

Regulations

$\begin{array}{lllllll}\text { ingpsiz1 } & 2088 & 0.10 & 0.07 & 0.11 & 1.10 & 0.91 \\ \text { ingpsiz2 } & 2088 & 0.05 & 0.05 & 0.05 & 1.00 & 0.33 \\ \text { ingpsiz3 } & 2037 & 0.04 & 0.04 & 0.03 & 0.75 & 0.82 \\ \text { ingpsiz4 } & 2088 & 0.02 & 0.03 & 0.02 & 1.00 & -0.01 \\ \text { chstf1 } & 2088 & 4.70 & 4.00 & 1.41 & 0.30 & 1.29\end{array}$

(table continues) 


\begin{tabular}{|c|c|c|c|c|c|c|}
\hline Variable & $N$ & Mean & Median & $\begin{array}{l}\text { Standard } \\
\text { Deviation }\end{array}$ & $\begin{array}{l}\text { Coeff. } \\
\text { Variation }\end{array}$ & Skewness \\
\hline chstf2 & 2088 & 5.97 & 6.00 & 1.88 & 0.31 & 0.80 \\
\hline chstf3 & 2088 & 10.15 & 10.00 & 2.68 & 0.26 & 0.33 \\
\hline chstf4 & 2088 & 13.63 & 12.00 & 3.81 & 0.28 & 0.43 \\
\hline visit & 2088 & 1.48 & 1.00 & 1.02 & 0.69 & 1.44 \\
\hline \multicolumn{7}{|c|}{ Cost of Inputs } \\
\hline cmedhour & 2088 & 7.40 & 6.70 & 2.61 & 0.35 & 1.83 \\
\hline cmedrent & 2088 & 72.00 & 66.88 & 29.09 & 0.40 & 0.78 \\
\hline
\end{tabular}

Provider

Characteristics

$\begin{array}{lllllll}\text { head } & 1972 & 0.12 & 0.00 & 0.32 & 2.67 & 2.36 \\ \text { pubsch } & 1972 & 0.21 & 0.00 & 0.41 & 1.95 & 1.42 \\ \text { religous } & 1972 & 0.12 & 0.00 & 0.33 & 2.75 & 2.31 \\ \text { forproft } & 1971 & 0.28 & 0.00 & 0.45 & 1.61 & 0.98 \\ \text { Mthsopn } & 1772 & 132.20 & 96.00 & 131.69 & 1.00 & 3.25 \\ \text { Numfees } & 1186 & 3.16 & 3.00 & 1.88 & 0.59 & 1.09 \\ \text { Ncentral } & 2088 & 0.23 & 0.00 & 0.42 & 1.83 & 1.27 \\ \text { south } & 2088 & 0.35 & 0.00 & 0.48 & 1.37 & 0.63 \\ \text { Neast } & 2088 & 0.20 & 0.00 & 0.40 & 2.00 & 1.46 \\ \text { west } & 2088 & 0.21 & 0.00 & 0.41 & 1.95 & 1.39 \\ \text { msa } & 2088 & 0.17 & 0.00 & 0.37 & 2.18 & 1.78\end{array}$


Descriptive Statistics

\begin{tabular}{llllllr} 
Variable & N & Mean & Median & $\begin{array}{l}\text { Standard } \\
\text { Deviation }\end{array}$ & $\begin{array}{l}\text { Coeff. } \\
\text { Variation }\end{array}$ & Skewness \\
\hline Rural & 2088 & 0.21 & 0.00 & 0.41 & 1.95 & 1.41 \\
Cencity & 2088 & 0.28 & 0.00 & 0.45 & 1.61 & 0.99 \\
Subsidy & & & & & & \\
\hline cPreK & 2088 & 388.68 & 193.58 & 656.86 & 1.69 & 4.29 \\
cSSBG & 2088 & 25.27 & 0.00 & 38.63 & 1.53 & 1.49 \\
CStatsub & 2088 & 97.24 & 40.51 & 150.98 & 1.55 & 2.38 \\
CJOBSper & 2088 & 15.03 & 6.02 & 19.23 & 1.28 & 1.48 \\
CHeadper & 2088 & 1524 & 531 & 5732 & 3.76 & 6.40 \\
Cmaxamt & 2088 & 227 & 0.00 & 347 & 1.53 & 2.16 \\
R_R & 2088 & 0.81 & 1.00 & 0.39 & 0.48 & -1.59 \\
CADCProv & 2088 & 0.48 & 0.00 & 0.50 & 1.04 & 0.09 \\
Refund & 2088 & 0.06 & 0.00 & 0.23 & 3.83 & 3.77 \\
Incomtax & 2088 & 0.86 & 1.00 & 0.35 & 0.41 & -2.09
\end{tabular}




\section{Functional Form And Statistical Analysis}

\section{Functional Form}

In child care literature the most common functional form for cost and quality is linear with the exception of family income which is curvilinear. Family income is entered in a curvilinear form to allow for nonlinearities. The variable family income was included in a linear as well as squared term and the other variables were entered in the linear term. This dissertation seeks to explore correct functional form for equations explaining child/staff and price of care.

It is crucial to have the model correctly specified so as to draw accurate conclusions from it. Economic theory, investigator's own perception about the theory and previous literature provide the initial formulation of econometric models. The researcher comes up with different models and puts them through a number of diagnostic tests and selects the most appropriate one.

One method of model selection is the general to simple model advocated by Hendry (1985) [see also Hendry and Richards $(1982,1983)]$. In the model selection process advocated by Hendry, which is also called "top-down" approach, the investigator starts with a general dynamic model and by using Wald and t-tests attempts to make the model more parsimonious. The advantages of such a parsimonious model are more degrees of freedom, greater power of test and a simpler model (Ramanathan, 1995). This dissertation will use the general to simple method of model selection. 
Statistical Analysis - Hendry's General to Simple Model

First the model was estimated for each of the three reduced form equations, by using multiple regression. The plot of residuals was checked for violations of the assumptions of OLS. The plot of residuals were heteroskedastic. All variables with |tratios $\mid<1$ were dropped (Huber, 1967 \# 1 as cited in Queralt and Witte, Working Paper Series, 1996). Next the Wald test (Greene, 1993) was performed to see if the dropped variables were jointly as well as individually insignificant. The final linear specification consists of only variables which have $\mid$ t-ratios $\mid<1$.The resulting final linear specification model that emerged for the three equations is given in Tables 4, 5 and 6. 
Table 4

Final Linear Specification Child Staff Ratio (Group Level)

\begin{tabular}{|c|c|c|c|c|}
\hline Variable & Coeff. & Std.Err & $\mathrm{t}$-value & p-value \\
\hline
\end{tabular}

Dependent

Ch_tchrg

Independent

Regulations

chstfl

ingpsiz2

ingpsiz3

$-0.091$

0.066

$-1.391$

0.165

9.624

3.718

2.588

0.010

$-5.970$

4.443

$-1.344$

0.179

Community

Characteristics

unemp

0.079

0.042

1.856

0.064

preschpr

3.374

1.469

2.297

0.022

Family

Characteristics

chld l per

cmedinc

4.082

1.903

2.145

0.032

$-0.000$

8.760

$-2.004$

0.045

Provider

Characteristics

head

0.521

0.349

0.273

1.907

0.057

religous

0.266

1.314

0.184

pubsch

0.419

0.228

1.840

0.066

forproft

0.324

0.207

1.562

0.119

Neast

$-0.972$

0.226

$-4.296$

0.000

Rural

$-0.816$

0.253

cencity

msa

$-0.432$

0.212

$-3.227$

0.001

$-2.041$

0.041

$-0.263$

0.257

$-1.022$

0.307

(table continues) 
Variable

Coeff.

Std.Err

$\mathrm{t}$-value

p-value

Cost of Inputs

cmedrent

0.008

0.004

1.931

0.054

Subsidy

CStatsub

$-0.002$

0.001

$-3.522$

0.000

CHeadper

$-0.000$

0.000

$-2.139$

0.033

R R

$-0.360$

0.245

$-1.470$

0.142 
Table 5

Final Linear Specification Child Staff Ratio (Center Level)

Variable Coeff. Std.Err t-value $\quad$-value

Dependent

Ch_ctr

Independent

Regulation

chstf2

0.205

0.134

1.535

0.125

chstf4

$-0.134$

0.068

$-1.952$

0.051

ingpsiz1

$-9.164$

2.922

$-3.136$

0.002

ingpsiz2

19.750

8.305

2.378

0.018

ingpsiz3

10.711

8.856

0.227

Community

Characteristics

Perwhite

3.762

1.624

2.317

0.021

PerBlack

2.180

1.638

1.331

0.184

Female

$-0.123$

0.034

$-3.579$

0.000

Family

Characteristics

Oldagepr

$-5.539$

3.644

$-1.520$

0.129

Provider

Characteristics

mthsopn

0.002

0.001

1.603

0.109

south

$-2.938$

0.636

$-4.622$

0.000

Neast

$-3.347$

0.540

$-6.200$

0.000

west

$-3.239$

0.593

$-5.461$

0.000

rural

$-1.296$

0.499

$-2.597$

0.009

Cost of Inputs cmedhour

0.284

0.078

3.657

0.000 
Table 6

Final Linear Specification Center Average Hourly Fee

Variable

Coeff.

Std.Err

t-value

$p$-value

Dependent

Cavgfees

Independent

Regulation

chstf1

chstf3

0.092

0.026

3.573

0.000

chstf4

0.088

0.026

3.399

0.001

chstf2

$-0.048$

0.015

$-3.297$

0.001

ingpsiz3

$-0.087$

0.026

$-3.328$

0.001

ingpsiz4

2.496

2.612

1.146

2.177

0.030

visit

$-0.042$

1.608

0.027

1.624

0.105

$-1.574$

0.116

Community

Characteristics

migrant

crime

preschpr

Pergenex
0.012

$-0.000$

$-1.247$

0.000
0.005

0.000

0.425

0.000
2.338

$-1.788$

$-2.938$

$-3.864$
0.020

0.074

0.003

0.000

Family

Characteristics

Femalper

cmedinc

cmedinc2

Provider

Characteristics

mthsopn

head

south

Neast
0.739

0.000

$-1.050$
0.275

8.520

7.420

2.688

2.547

0.007

0.011

$-1.414$

0.158 
Variable

west

cencity

msa

Cost of Inputs

cmedrent

0.006

0.001

4.396

0.000

Subsidy
cPreK
cSSBG
CStatsub
CJOBSper
R_R

Coeff.

$-0.304$

0.163

0.154

0.106

0.083

0.092

$-2.866$

0.004

1.970

1.677

0.049

0.094

Std.Err $t$-value $p$-value

\begin{tabular}{ll}
$1.677-0.094$ \\
\hline
\end{tabular}

4.390

$-3.920$

0.000

0.004

0.000

3.892

0.000

0.000

0.000

1.641

0.101

0.004

0.002

1.816

2.052

0.070

0.007 
Next the possibility of nonlinearities in the explanatory variables in the Final Linear Specification was examined. For this procedure, the variables from each of the Final Linear Specification in their linear terms, all continuous variables in their squared terms and all possible interactions among the variables were regressed on each of the dependent variables. For example, for the child/staff ratio at the group level, from the final linear specification for the child/staff (group) equation the explanatory variables in their linear term, the continuous variables in their squared terms and all possible interactions among the explanatory variables were regressed on the dependent variable which is the child/staff ratio at the group level.

The nonlinear equation that emerged for the child/staff at the group level was :

Ch_tchrg $=\beta_{0}+\beta_{1} \mathrm{x}_{\mathrm{i} 1}+\beta_{2} \mathrm{x}_{\mathrm{i} 2}+\beta_{3} \mathrm{x}_{\mathrm{i} 1}{ }^{2}+\beta_{4} \mathrm{x}_{\mathrm{i} 2}{ }^{2}+\beta_{5} \mathrm{x}_{\mathrm{i} 1} \mathrm{x}_{\mathrm{i} 2}+\varepsilon$ where $\mathrm{Ch}_{-}$tchrg is the child/staff ratio at the group level. $\mathrm{Xi1}, \mathrm{Xi} 2, \ldots . \mathrm{Xi}_{\mathrm{n}}$ are continuous independent variables in their linear terms, $\mathrm{x}_{\mathrm{i} 1}{ }^{2}, \mathrm{x}_{\mathrm{i} 2}{ }^{2}$ are the squared terms and $\mathrm{X}_{\mathrm{i} 1} \mathrm{X}_{\mathrm{i} 2}$ are interaction terms and $\boldsymbol{\varepsilon}$ is the error term.

Highly correlated variables were then dropped. Then to reduce the specifications, all variables with $\mid$ t-ratios $\mid<1$ were dropped. The dropped variables were then jointly as well as individually tested for significance using Wald test. This procedure was repeated until all variables with $\mid \mathrm{t}$-ratios $\mid<1$ had been dropped.

For the average fees equation the procedure followed was slightly different. First a stepwise regression procedure was used to choose those variables which were 
significant. This was necessary because the non linear specification for the fees equation was too large.Then the variables with $|t-r a t i o s|<1$ were dropped and the dropped variables were then tested jointly as well as individually for significance using Wald test. This became Hendry's general to simple model. Tables 7, 8 and 9 give the significant variables for the general to simple method.

To explain the coefficient of the squared and the interaction terms we have to calculate the partial derivative and the elasticities. The partial derivative which is calculated at the median values of the explanatory variable shows the effect of a unit change in the explanatory variable, on the dependent variable. The elasticities denote the percent change that could occur in the dependent variable for one percent change in the explanatory variable. The effects implied by this specification are summarized in Tables 10,11 and 12 (Empirical Results). 
Table 7

Significant General to Simple --Group

Variable

Linear Square Interaction

Coeff. p-value

Coeff. Coeff. with

Cost of Inputs

cmedrent

$-0.0165$

$(0.047)$

Subsidy

CStatsub

0.0031

ingpsiz3

$-0.0868 \quad 0.014$

$(0.161)$

R_R

Neast
ingpsiz2

$\begin{array}{ll}-0.7970 & 0.002\end{array}$

Community

Characteristics

Preschpr

33.7050 Religous

$\begin{array}{ll}11.1158 & 0.007\end{array}$

(0.000) ingpsiz3

$\begin{array}{ll}-94.6849 & 0.021\end{array}$

cmedrent

$\begin{array}{ll}0.0772 & 0.032\end{array}$

cmedinc

$\begin{array}{ll}-0.0004 & 0.000\end{array}$

Unemp

chstf1

$0.1503 \quad 0.216$

pubsch

$0.1960 \quad 0.037$

$\underline{\text { Regulations }}$

ingpsiz3

56.9565

(0.230)

chstf1

head

$-0.1478$

0.220

(table continues) 
Variable

$$
\text { Linear }
$$

Square Interaction

Coeff.

p-value

Coeff. Coeff. with

Provider

Characteristics

pubsch

$-3.9148$

rural

cencity

cmedinc

rural

cmedinc

CHeadper

Forproft

(0.014)

head

religous

rural

$\begin{array}{ll}-1.7229 & 0.000\end{array}$

$-1.0101 \quad 0.010$

$0.0000 \quad 0.021$

$\begin{array}{ll}-2.0311 & 0.004\end{array}$

$\begin{array}{ll}-0.0000 & 0.043\end{array}$

$0.0000 \quad 0.273$

Family

Characteristics

Chld1per

pubsch

$9.9528 \quad 0.007$

forproft

$1.6881 \quad 0.005$

cmedinc

9.0300 ingpsiz3

$0.0005 \quad 0.023$

(0.012) 
TABLE 8

Significant General to Simple - Child Staff Ratio

\begin{tabular}{llll}
\hline Variable & Linear Square & Interaction & Coeff. p-value \\
& Coeff. Coeff. & with
\end{tabular}

$\underline{\text { Regulations }}$

Chstf4

Ingpsiz3

171.0955

(0.003)

Rural

ingpsiz1

$-29.3883$

0.000

ingpsiz2

56.0912

0.003

Community

Characteristics

Perwhite

PerBlack

Female

$$
-0.0027
$$

(0.000)

south

Neast

$-13.8396$

0.000

chstf2

1.7656

0.287

south

0.5347

0.001

$-9.9438$

0.002

Oldagepr

$-41.42744$

(0.227)

Cost of Inputs

cmedhour

ingpsiz1

$-0.4141$

0.162

Provider

Characteristics

Neast

$-4.9076$

(0.001)

mthsopn

south

$$
\begin{aligned}
& -6.5700 \\
& (.001)
\end{aligned}
$$

Oldagepr

south

west

$-22.2108$

0.000

0.7467

0.207

0.002

0.1548 rural

$-2.1655$

0.0084

0.0874

2.2148
0.201

0.020

0.000

0.147 
TABLE 9

Significant General to Simple- Average Fees

\begin{tabular}{llll}
\hline Variable & $\begin{array}{l}\text { Linear Square } \\
\text { Coeff. Coeff. with }\end{array}$ & Interaction & Coeff. p-value \\
& &
\end{tabular}

\begin{tabular}{lllll}
\hline Regulations & & & & \\
Ingpsiz3 & 14.1479 & cmedrent & -0.1302 & 0.001 \\
& $(0.000)$ & cPreK & -0.0144 & 0.000 \\
& & cSSBG & -0.1246 & 0.000 \\
Chstf1 & & Femalper & -0.2898 & 0.080 \\
& & preschpr & -0.5166 & 0.008 \\
& & Mthsopn & 0.0004 & 0.008 \\
Chstf2 & cmedrent & 0.0035 & 0.000 \\
Chstf3 & R_R & -0.0675 & 0.000 \\
& & Femalper & 0.1333 & 0.056 \\
Chstf4 & & mthsopn & 0.0004 & 0.000 \\
& & mthsopn & -0.0002 & 0.008 \\
visit & & south & -0.1285 & 0.000 \\
& & cmedrent & -0.0049 & 0.000
\end{tabular}

Community

Characteristics

\begin{tabular}{lllll}
\hline Preschpr & 4.0572 & CJOBSper & -0.0285 & 0.016 \\
& $(0.005)$ & mthsopn & -0.0069 & 0.005 \\
& & visit & 1.1865 & 0.000 \\
& & cmedrent & -0.0375 & 0.000 \\
Femalper & 2.1127 & Pergenex & 0.0003 & 0.021 \\
& $(0.001)$ & CStatsub & 0.0087 & 0.000 \\
& & south & -0.5403 & 0.235 \\
& & preschpr & -7.1634 & 0.002 \\
& & head & -0.9635 & 0.005 \\
& & msa & -1.1103 & 0.018 \\
& & cPreK & 0.0005 & 0.014
\end{tabular}

Provider

Characteristics

head

$\begin{array}{lll}\text { cPreK } & 0.0004 & 0.001 \\ \text { cSSBG } & 0.0030 & 0.048 \\ \text { ingpsiz4 } & 5.6663 & 0.041\end{array}$

(table continues) 


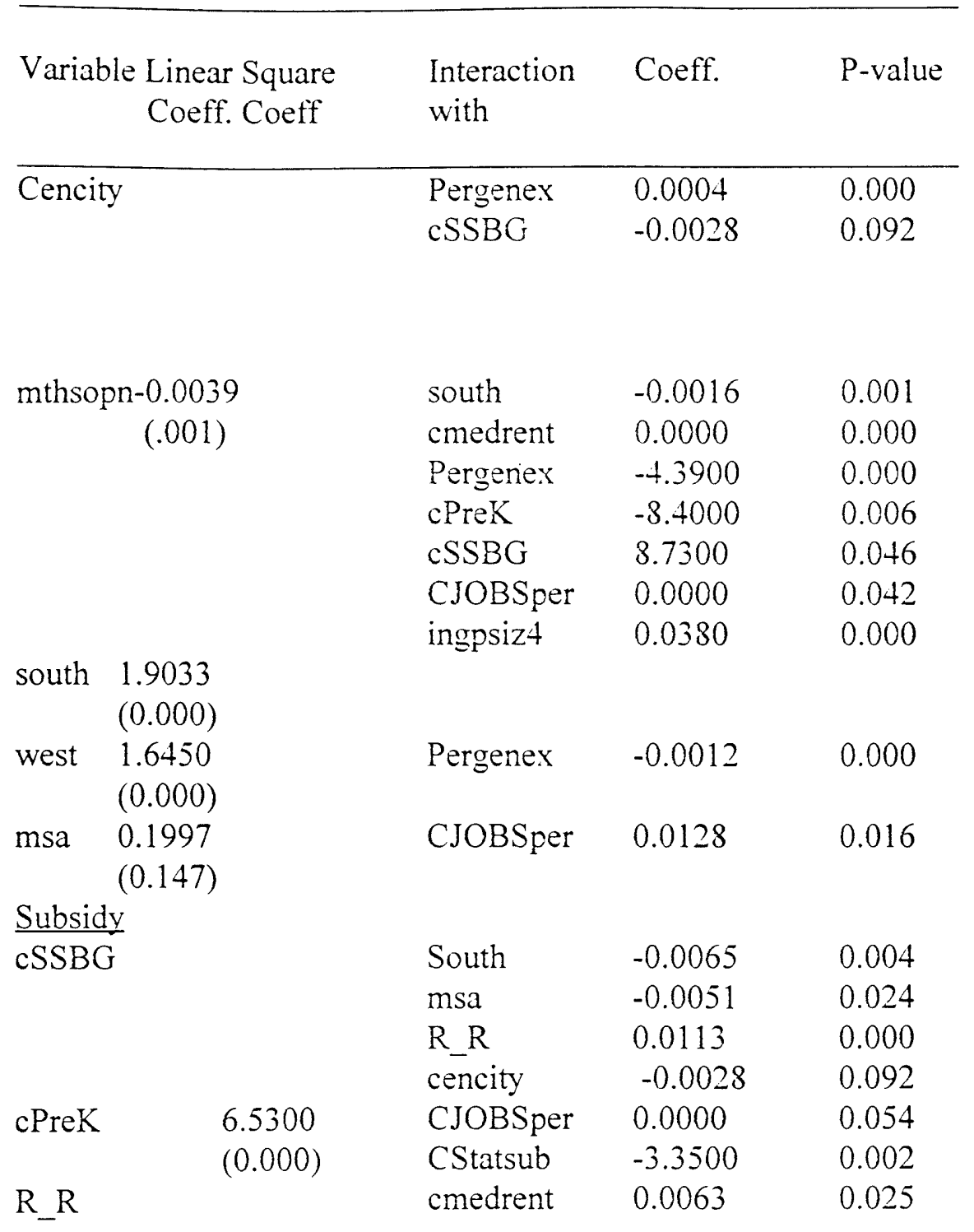


Table 10

Nonlinear Specification-- Child/Staff Ratio (Group)

Variable Effect on Child/Staff Elasticity

Ratio (Group)

(Partial Derivatives)

Family

Characteristics

cmedinc

$-0.000014$

$-0.05604$

Community

Characteristics

preschpr

1.061066

0.027408

Unemp

0.054123

0.000466

Cost of Inputs

cmedrent

0.016206

0.133318

$\underline{\text { Subsidy }}$

CStatsub

R_R

$-0.00039$

$-0.00193$

0.43345

0.053315

Provider

Characteristics

Religious

$-1.60207$

Head

0.742094

$\underline{\text { Regulations }}$

Ingpsiz3

$-2.24131$

$-0.01103$

Note. Elasticities are calculated at the median values. 
Table 11

Nonlinear Specification--Child/Staff Ratio (Center)

$\begin{array}{lll}\text { Variable } & \text { Effect on Child/Staff } & \text { Elasticity } \\ & \text { Ratio (Center) } & \\ & \text { (Partial Derivatives) }\end{array}$

Family

Characteristics

$\begin{array}{lll}\text { Oldagepr } & 1.883039 & 0.027199\end{array}$

Community

Characteristics

Female

Perwhite

Provider

Characteristics

Rural

Mthsopn

$\underline{\text { Regulations }}$
$-0.21637$

3.208047

$-0.72134$

0.00311
$-1.39437$

0.313676

0.033174

$\begin{array}{lcc}\text { Ingpsiz3 } & 13.68764 & 0.060834 \\ \text { Ingpsiz2 } & 8.393261 & 0.046629 \\ \text { Ingpsiz1 } & -2.77446 & -0.02158 \\ \text { chstf4 } & 0.020434 & 0.027245 \\ \text { chstf2 } & 0.226262 & 0.150841\end{array}$

Note. Elasticities are calculated at the median values. 
Table 12

Nonlinear Specification-- Average Fees

Variable

Effect on Average Fees

Elasticity

(Partial Derivatives)

Family

Characteristics

Femalper

$-0.50884$

$-0.06$

Community

Characteristics

preschpr

$-1.57799$

$-0.25$

Cost of Inputs

cmedrent

0.005772

0.29

Subsidy

cSSBG

cPreK

0.007112

0.57

CStatsub

$-0.00036$

$-0.05$

0.00118

0.04

CJOBSper

$-0.00113$

$-0.01$

R_R

$-0.20$

$-0.15$

Provider

Characteristics

Mthsopn

0.0009585

0.000019

Head

0.08 
Variable

Effect on Average Fees

(Partial Derivatives)

Elasticity

$\underline{\text { Regulations }}$

$\begin{array}{llc}\text { Visit } & -0.081577 & -0.06 \\ \text { Ingpsiz4 } & 3.645552 & 0.08 \\ \text { Ingpsiz3 } & 2.657099 & 0.08 \\ \text { Chstf4 } & -0.02 & -0.15 \\ \text { Chstf3 } & 0.06 & 0.44 \\ \text { Chstf2 } & -0.0675 & -0.30 \\ \text { Chstf1 } & 0.12 & 0.35\end{array}$

Note. Elasticities are calculated at the median values except for cSSBG which is calculated at the 75 th Percentile. 


\title{
CHAPTER SIX
}

\section{EMPIRICAL RESULTS AND POLICY IMPLICATIONS}

\author{
Interaction Effects
}

\section{Significant Explanatory Variable Effects on Child/Staff Ratio at the Group Level}

In this model the dependent variable is the child/staff ratio at the group level in the center. Table 10 gives the empirical interaction results of significant explanatory variable effects on the child/staff ratio at the group level.

Cost of living adjusted state subsidy per child in poverty $3-13$ vears (Figure 1)

The negative partial derivative means that for a unit increase in cost of living adjusted state subsidized care per child in poverty, there is a unit decrease in the child/staff ratio at the group level. The elasticity of a negative 0.002 means that for one percent increase in the State subsidy per child in poverty, there is a $0.002 \%$ decrease in the child /staff ratio at the group level.

The state subsidy graph (Figure 1) shows a negatively decelerating curve, which indicates that for every one unit increase in the state subsidy per poor child there is a unit decrease in the staff/child ratio. For example if the state subsidy increases from $\$ 100$ per poor child to $\$ 200$ per poor child, the staff/child ratio at the group level decreases from 18.13 to 18.09 . It is possible that as more subsidies become available to the centers, they increase the number of staff per child. This finding confirms previous studies that lowincome children receive better quality of care (National Child Care Staffing Study, 1989). 
It is also worth noting that the interaction between state subsidy and inverse maximum group size for $25-36$ months is also significant ( $\mathrm{p}$ value of 0.014 ), as given in Table 7 . Figure 2 shows the interaction between cost adjusted state subsidy per child in poverty and inverse maximum group size for $25-36$ months. when the regulation is stringent, lax ( the most lax is the mean) and at the median level. When the maximum group size is stringent for a given level of subsidies, the child/staff ratio decreases rapidly. At the median level the decrease is less rapid and when the regulation is lax, the curve actually rises at a very slow rate. We can conclude that state subsidy seems to be most effective when the maximum group size regulation is most stringent.

Inverse maximum group size ( $25-36$ months) and center regulations (Figure 3 )

Figure 3 indicates that as the maximum group size increases (lower the inverse) the center child ratio at the group level increases. The elasticity of -0.01 indicates that for every $1 \%$ increase in the inverse of the maximum group size permitted in centers, there is a corresponding decrease of $0.01 \%$ in the child/staff ratios at the group level at such centers.

The curve is a positively accelerating curve. The curve accelerates at a faster rate when the maximum group size is very stringent (between 5 and 10) when compared to a less stringent maximum group size. As these regulations become more stringent the centers decrease the number of children per staff. This is an example of spillover effects of center regulations. 


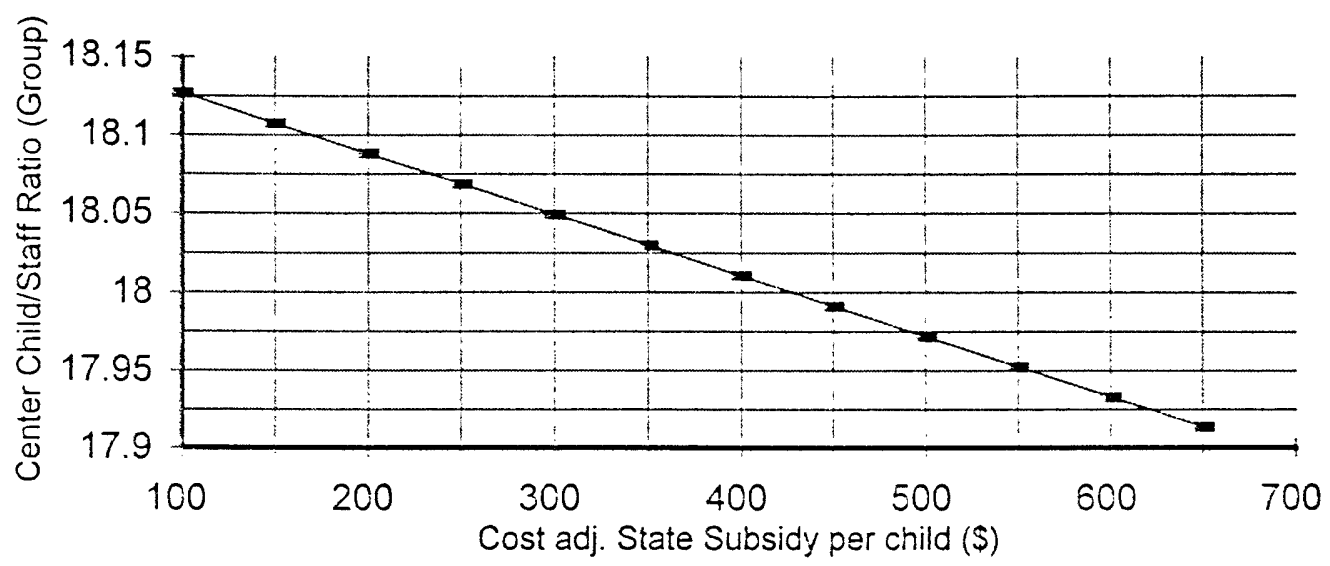

Figure 1. Effect of Cost adjusted (adj.) state subsidy on center child/staff ratio (group level) 


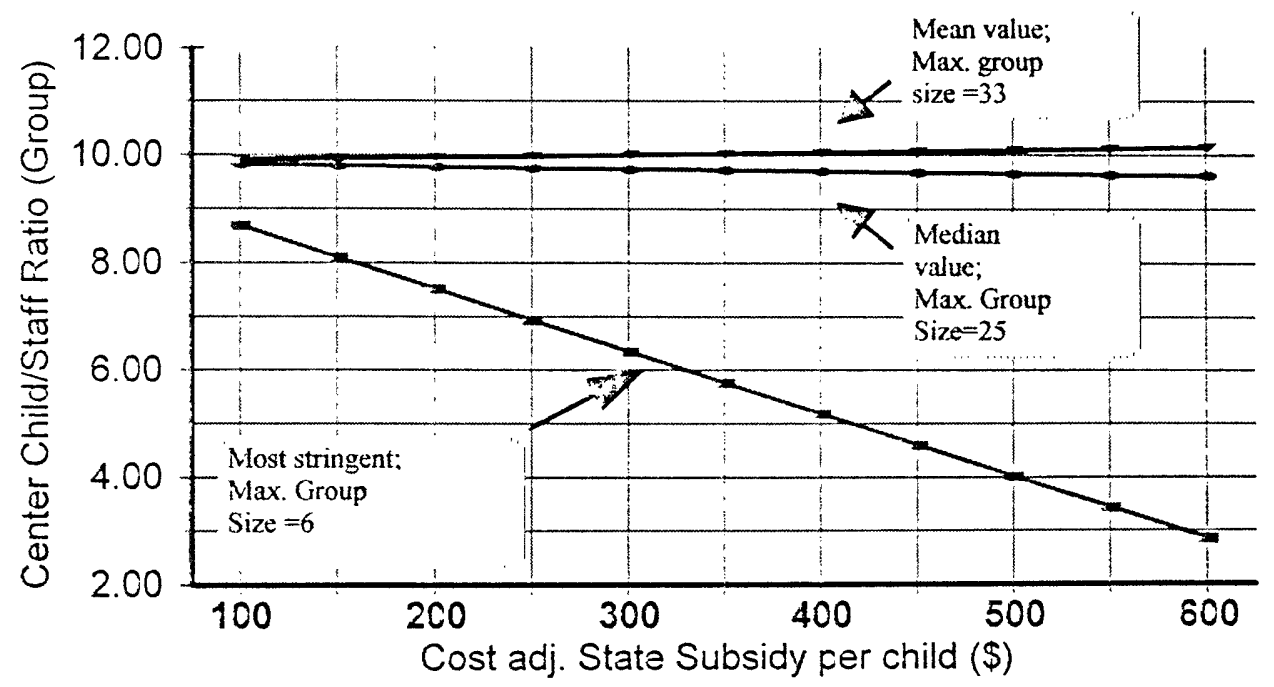

Figure 2. Interaction of Cost adjusted (adj.) state subsidy and maximum group size regulations for ages 25-36 months on center child/staff ratio (group level) 


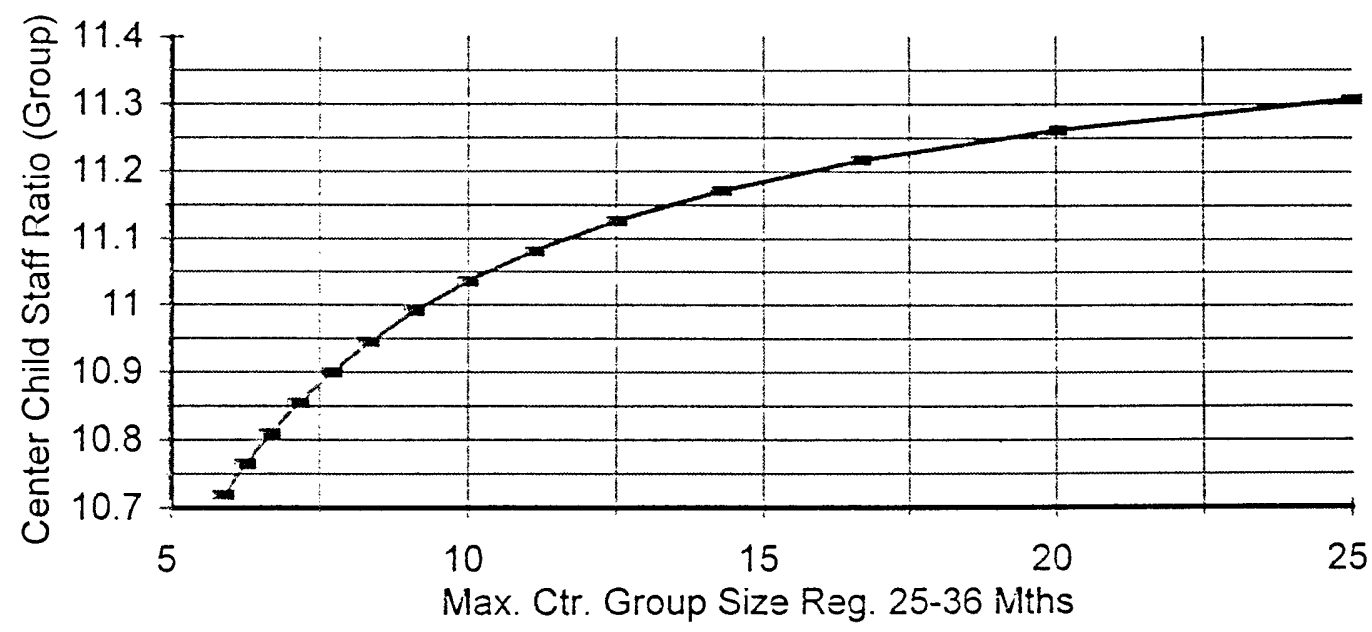

Figure 3. Effect of maximum center (Max. Ctr) group size regulation (Reg.) for 25-36 months (Mths.) on child/staff ratio (group) 
Resource and referral agency and center location in the north east (Figure 4)

If the community where the center is located has a Resource and Referral (R_R) agency and the center is located in the North East, then the mean value of the child/staff ratio for the group is a low 7.72 when compared to 8.63 when there is no $R_{-} R$ agency and the center is not located in the North East (Figure 4). When there is no R_R agency and when the center is located in the North East the mean value of the child/staff ratio is 7.82 . When there is an R_R agency and the center is not located in the North East the mean value of the child/staff ratio is 8.68 . The interaction of $R \_R$ and North East is significant. The interaction between $R_{-} R$ and inverse of maximum group size (13-24 months) is also significant. See Table 7.

\section{Public school sponsor and center location in the rural area (Figure 5)}

If the center is public school sponsored and located in the rural area, mean value of the child/staff ratio at the group level is significantly low at 8.31 (Figure 5).

When a center is not public school sponsored and not located in the rural area the mean value of child/staff ratio is 8.47 . When the center is not public school sponsored and located in a rural area the mean value of the child/staff ratio is 8.17 and when the center is public school sponsored and not located in a rural area the mean child/staff ratio is 8.84 . The interaction of public school sponser and location in the rural area is significant. See Table 7. 
Church sponsor and center location in the rural area (Figure 6)

If the center is church sponsored and located in the rural area, the mean value of the child/staff ratio at the group level is a low 7.08 . When a center is not church sponsored and not located in the rural area the mean child/staff ratio is 8.52 . When the center is not church sponsored but located in a rural area the mean child/staff ratio is 8.73 . When the center is church sponsored and not located in a rural area the ratio is 8.30 . 


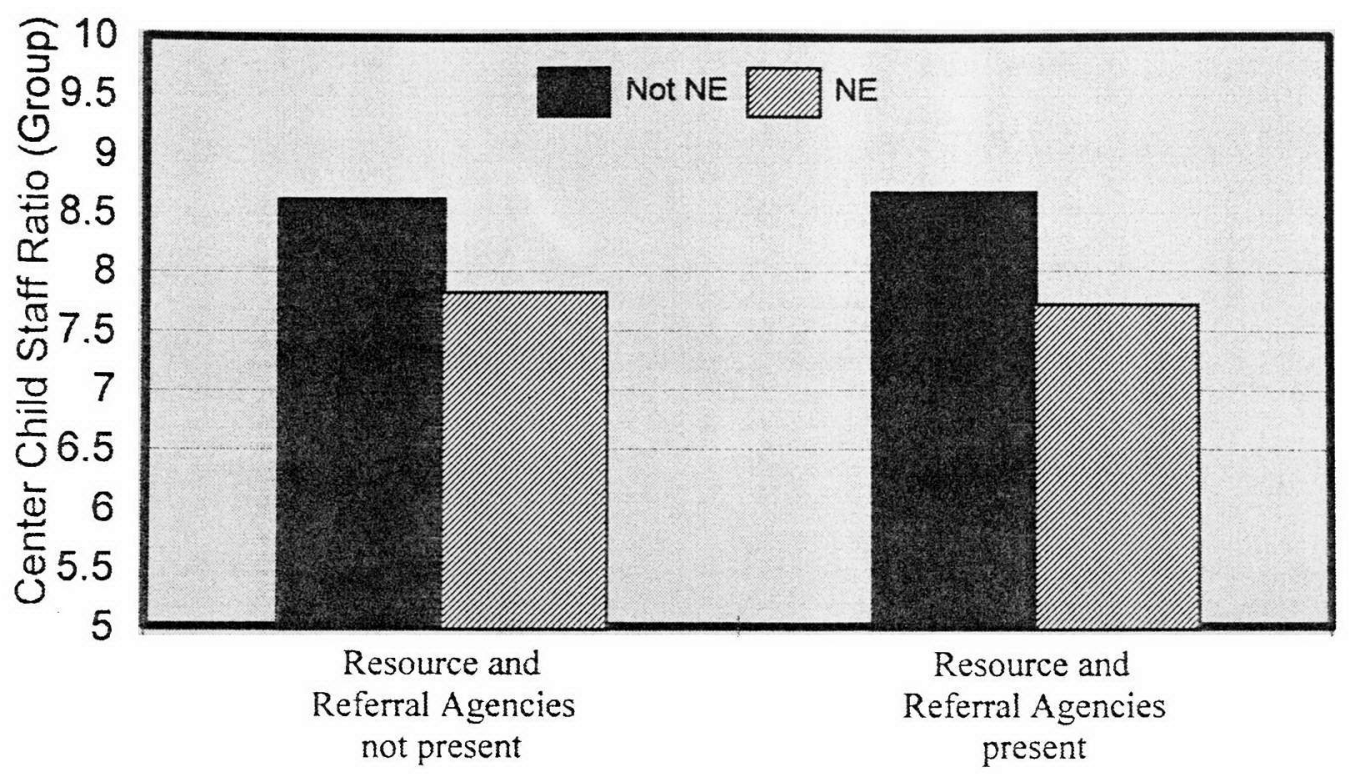

Figure 4. Interaction of resource and referral agencies and center location in the north east (NE) 


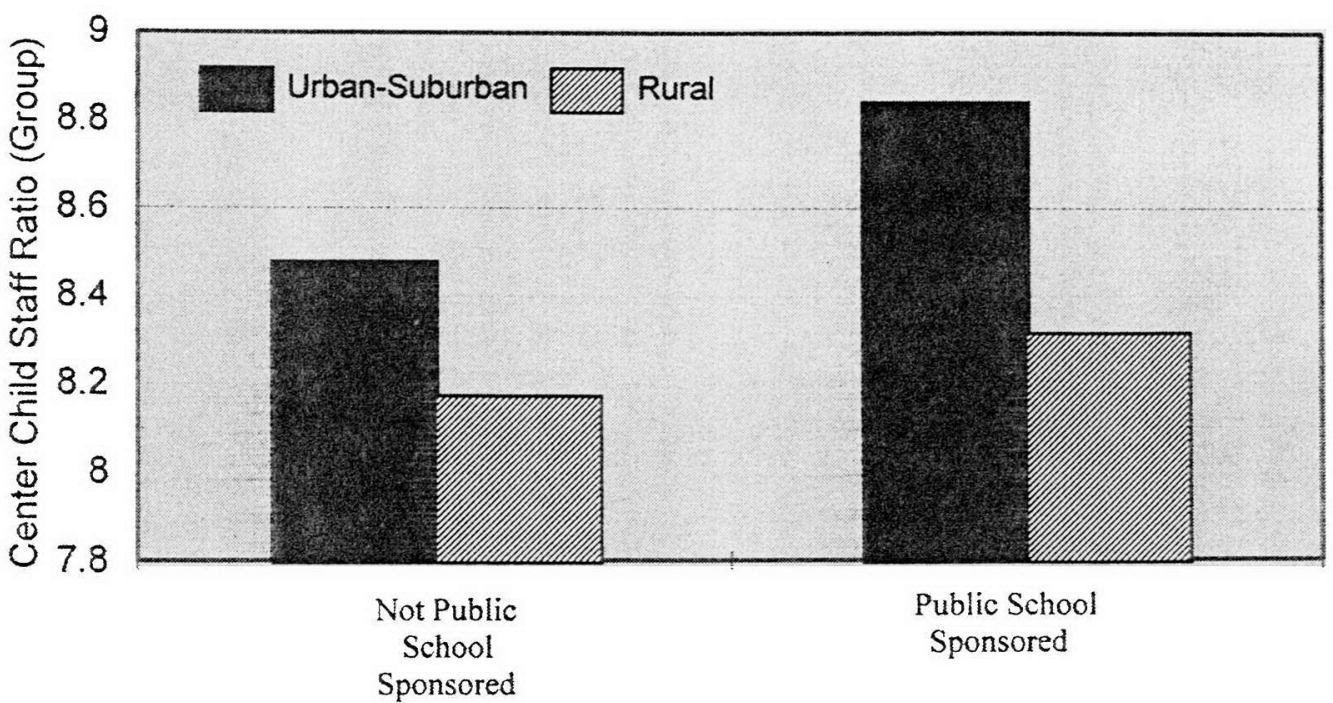

Figure 5. Interaction between public school sponsored center and location in a rural area 


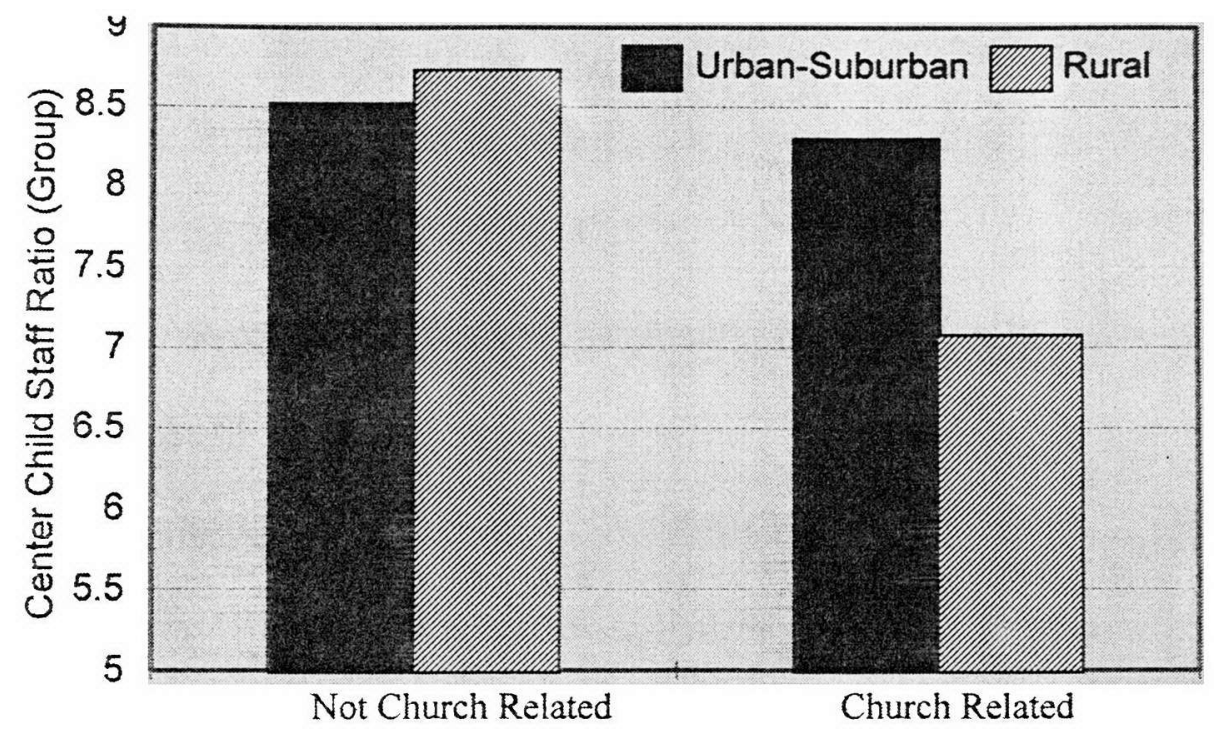

Figure 6. Interaction between church sponsored center and location in a rural area 


\section{Public School sponsor and center location in a central city (Figure 7)}

If the center is public school sponsored and located in central city the mean value of the child/staff ratio is significantly low at 8.10 . When a center is sponsored by a public school and not located in the central city the mean value of the child/staff ratio is 8.97 . When a center is not sponsored by a public school and not located in the central city the mean value of the child/staff ratio is 8.41 .

\section{$\underline{\text { Resource and Referral Agency and Inverse of maximum group size (13-24 }}$}

\section{months) (Figure 8)}

When we compare the effect of presence of Resource and Referral (R_R) agencies in the center PSU area, we can draw some interesting conclusions. The child/staff ratio is always higher for centers with $R$ _ $R$ when compared to centers which no $R \_R$ agencies. This finding reveals that resource and referral agencies play a significant role as providers of consumer information. Parents being concerned about quality in child care centers may find the presence of $R \_R$ agencies reassuring. The interaction of $R \_R$ and inverse maximum group size for 13-24 months is also significant. See Table 7. 


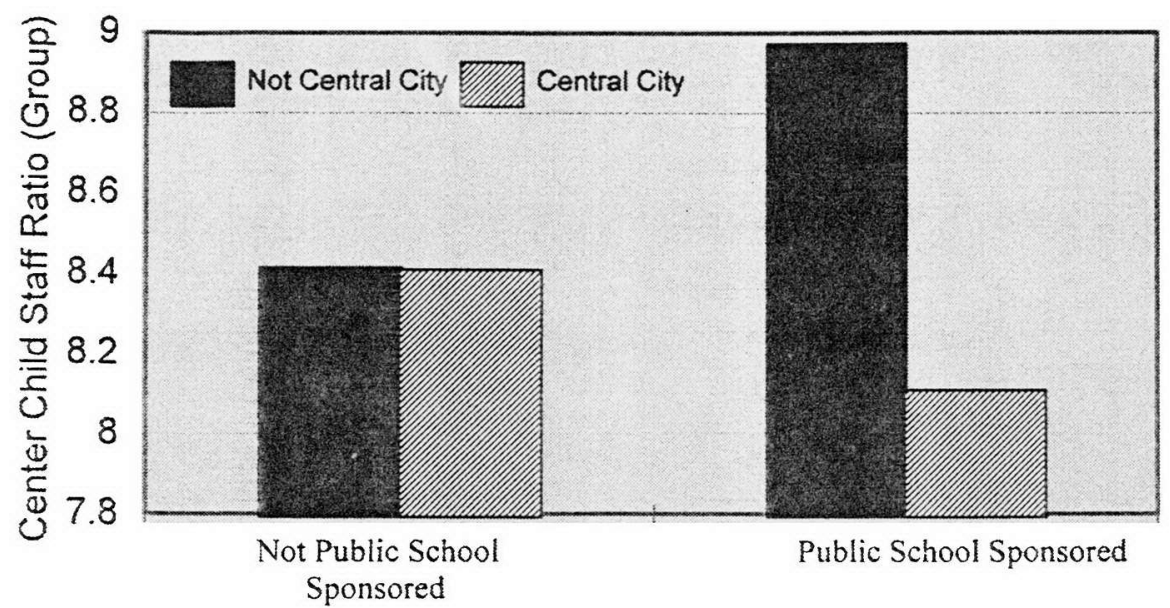

Figure 7. Interaction between public school sponsored center and location in a central city 


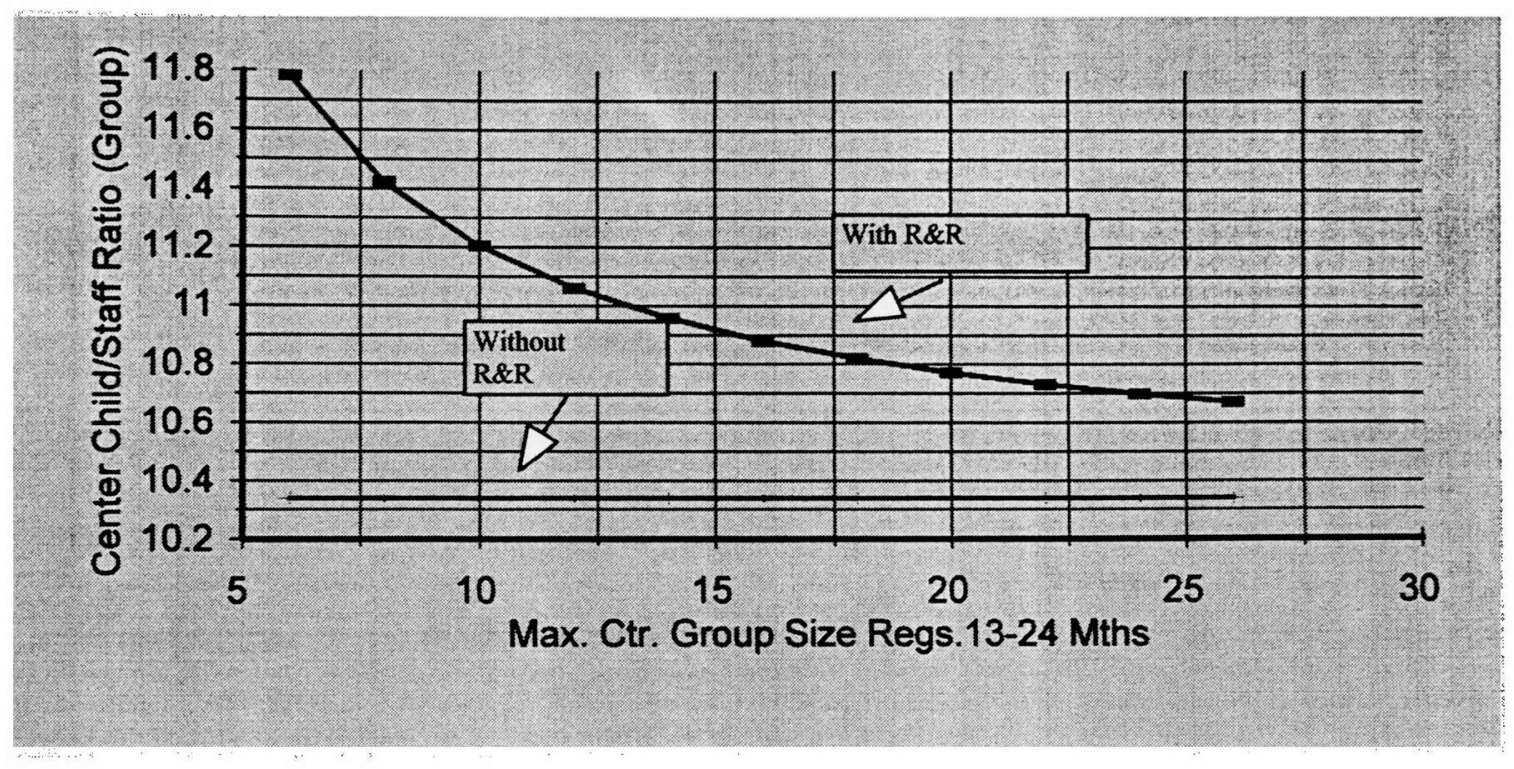

Figure 8. Effect of interaction of resource and referral agency and maximum center

(Max.Ctr. ) group size regulation (Reg.) 13-24 months (Mths.) on center child/staff ratio (group) 
Significant Explanatory Variable Effects on Child/Staff Ratio at the Center Level

In this specification, the dependent variable is the Child Staff Ratio at the center level. Table 11 summarizes its interaction effects.

Effect of Center Maximum Child Staff Ratio Regulation ( 37 months to 4 years) on Child Staff Ratio at the center level (Figure 9)

The positive partial derivative of 0.02 , suggests that for every one unit increase in the maximum child staff regulation for children between the ages of 37-60 months, there is a unit increase in the center child staff ratio. The elasticity of $0.03 \%$ indicates that if the maximum child staff regulation increases by $30 \%$, for example from 10 children per staff to 13 children per staff, the corresponding increase in the child staff ratio for the center is $1 \%$.

The curve as shown in the graph is a linearly accelerating curve which means that for every unit increase in the maximum child staff ratio regulation, there is an increase in the child staff ratio. The explanation for this behavior seems logical. As the regulation is relaxed, the centers increase the child staff ratio to obviously conserve financial resources. The interaction of maximum child staff regulation for ages 37-60 months, with center location in a rural area and with maximum child staff regulation for ages 13-24 months are significant. See Table 8. 


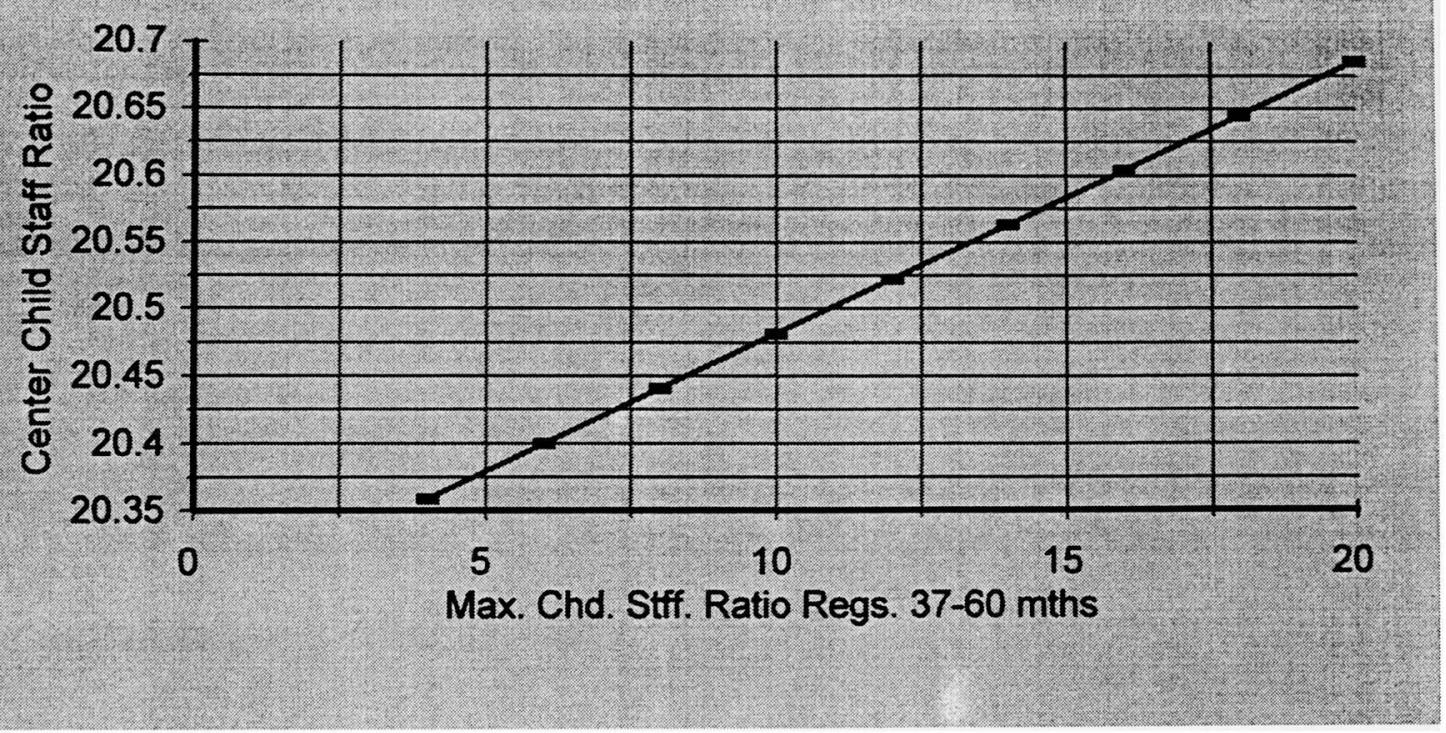

Figure 9. Effect of maximum center child staff ratio regulation (Max. Chd. Stff. Ratio Reg) for 37-60 months (Mths.) on center child staff ratio 
Effect of Inverse Maximum Group Size (25-36 months) on Center Child Staff Ratio

(Figure 10)

The positive partial derivative of 13.69 , indicates that for every one unit increase in the inverse maximum group size regulation (as the maximum group size decreases), the center child staff ratio increases. The elasticity of 0.06 indicates that for every $1 \%$ increase in the inverse of the maximum group size permitted in centers, there is a corresponding increase of $0.06 \%$ in the child/staff ratios at such centers. If the maximum group size decreases from 10 (an inverse of 0.1 ) to 6.67 (an inverse of 0.15 ), the child/staff ratio increases from 11.86 to 12.21 .

The curve is a negatively decelerating curve. The curve decelerates at faster rate when the maximum group size is very stringent (between 5 and 10) when compared to a less stringent maximum group size. As the regulations become more stringent the centers increase the number of children per staff. 


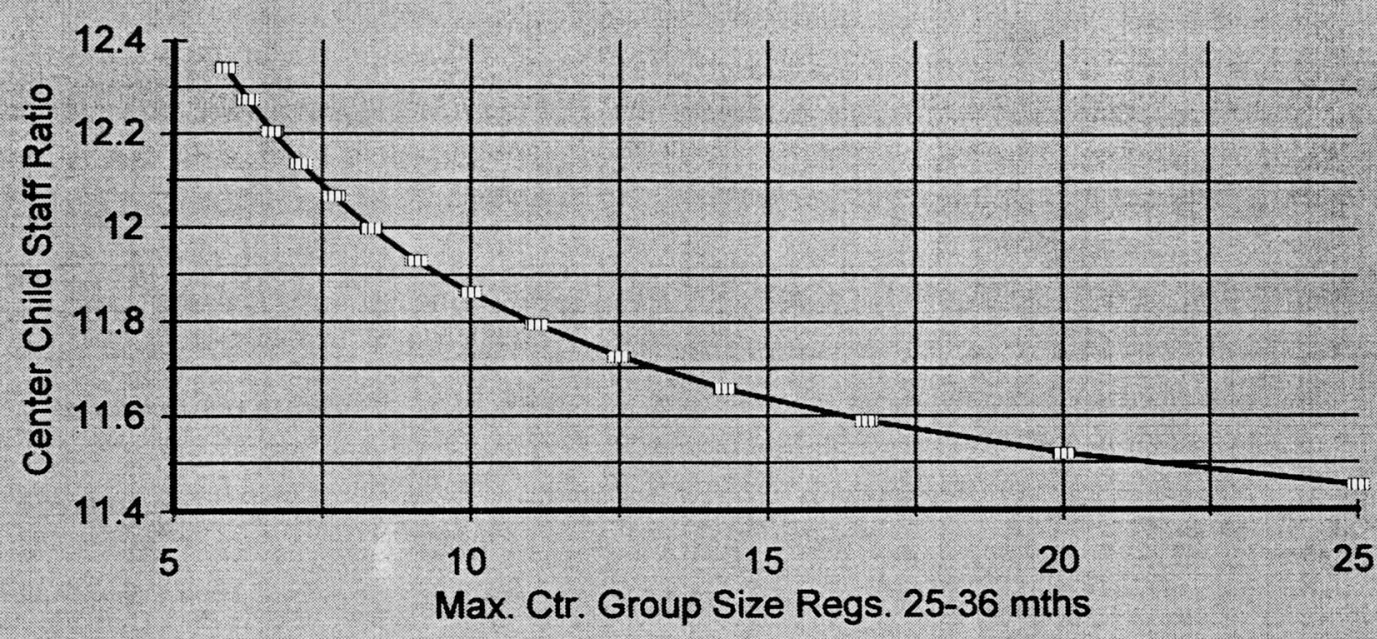

Figure 10. Effect of maximum center (Max. Ctr.) group size regulation (Regs.) for age 25-36 months (Mths.) on center child staff ratio 
Effect of center group size regulation 0-12 months on child staff ratio (Figure 11)

The negative partial derivative of -2.77 , indicates that for every one unit increase in the inverse maximum group size regulation ( the maximum group size decreases), the center child staff ratio increases. The curve is positively accelerative curve. The curve accelerates at a faster rate when the maximum group size is very stringent (between 5 and 10) when compared to a less stringent maximum group size. As the regulations become more stringent the centers decrease the number of children per staff.

Interaction of center group size regulation 0-12 months and location in a rural area (Figure 12)

The interaction of maximum center group size regulation 0-12 months and location in a rural area is significant. See Table 8 . When the center is located in a rural area the child/staff ratio is significantly lower (Figure 12). Another major finding is that location in a rural area has a significantly lower child/staff ratio (Table 11). 


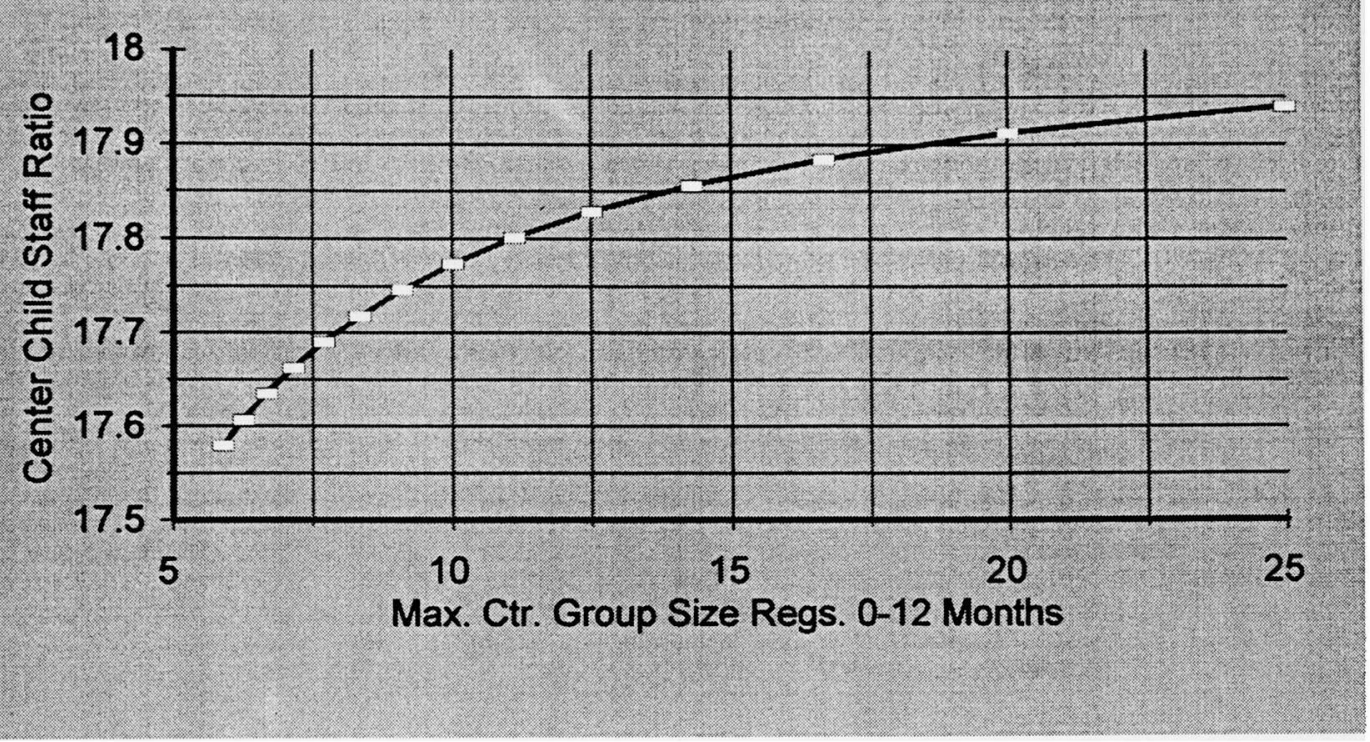

Figure 11. Effect of maximum center (Max. Ctr.) group size regulation (Regs.) 0-12 months (Mths.) on child staff ratio 


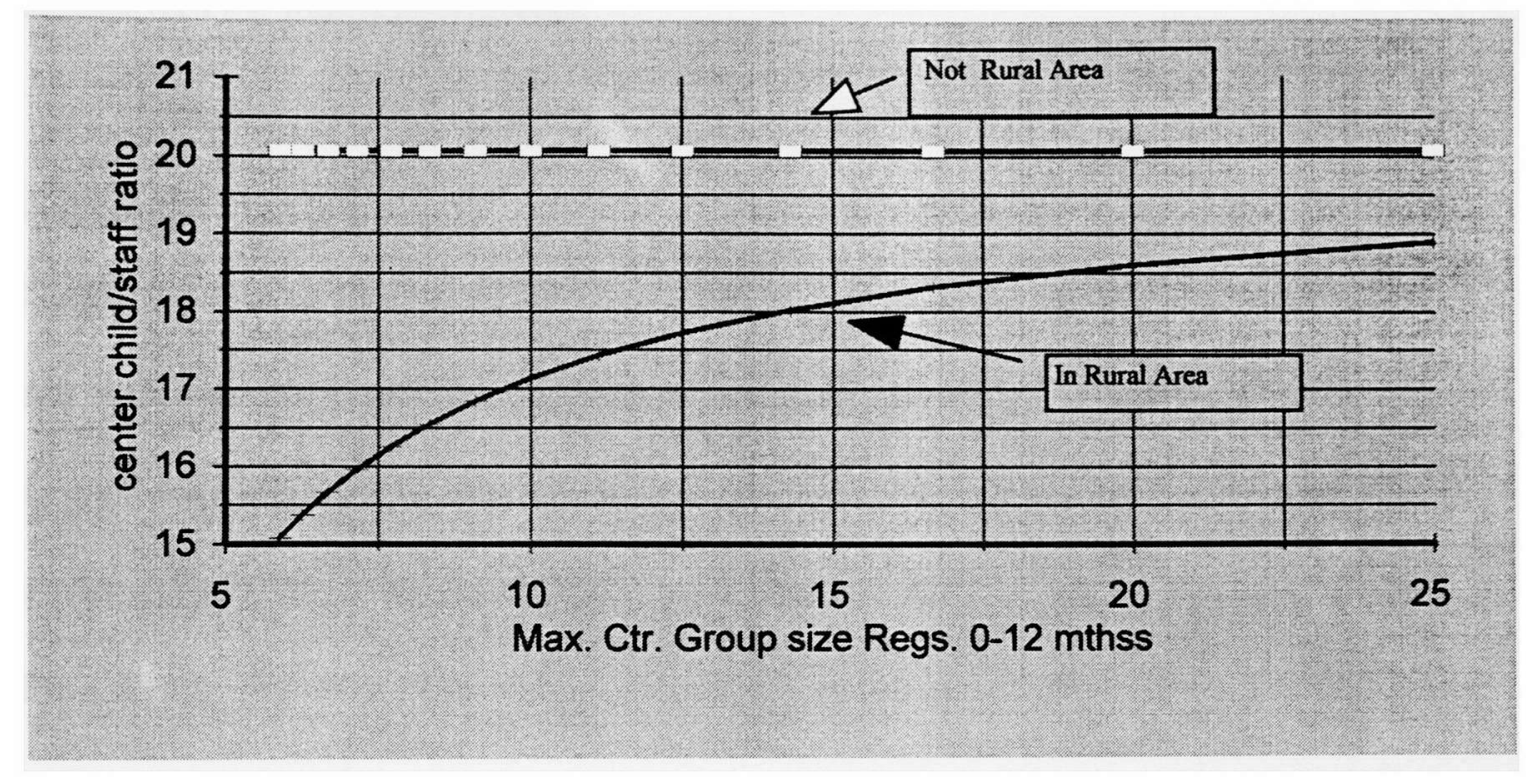

Figure 12. Interaction between maximum center (Max. Ctr.) group size regulation (Regs.) for 0-12 months (Mths.) and center location in a rural area 
Significant Explanatory Variable Effects on Average Fees at the Center Level

The dependent variable is the weighted average fees for each center. Table 12 summarizes the interaction effects.

Effect of Inverse Maximum Group Size (37-60) months on the Center hourly fee

\section{(Figure 13)}

The positive partial derivative of 3.65 indicates that for every one unit increase in the inverse maximum group size regulation (maximum group size decreases), the average hourly fee increases. The elasticity of 0.08 indicates that for every $1 \%$ increase in the inverse maximum group size regulation, the increase in the average hourly fee is $0.08 \%$.

The curve as shown in Figure 13 is a negatively decelerating curve. The curve decelerates at faster rate when the maximum group size is very stringent (between 5 and 10) when compared to a less stringent maximum group size. As the regulations become more stringent the hourly fee increases. To keep costs down, centers increase the price of care when regulations become stringent.

If the maximum group size decreases from 10 (an inverse of 0.1 ) to 6.67 (an inverse of 0.15 ), the hourly fee increases from $\$ 6.58$ to $\$ 6.76$.

Effect of Maximum Child Staff Ratio Regulation (0-12 months) (Figure 14):

The partial derivative is 0.12 and elasticity is 0.35 . When the maximum child staff ratio increases by $1 \%$ the hourly fee increases by $0.35 \%$.This is surprising. The curve is positively accelerating. When the maximum Child Staff ratio is 4 the average hourly fee is $\$ 6.95$ and when the maximum child staff ratio is 10 the average hourly fee is $\$ 7.67$. 
As summarized in Table 12, when the maximum child staff ratio for ages 25-36 months becomes more stringent the hourly price increases. Whereas for maximum child staff ratio for ages 13-24 months and 37-60 months the findings are opposite. When these regulations become stringent, the hourly price increases.

Interaction of Resource and Referral Agencies and Maximum Child Staff Ratios for ages 13-24 Months (Figure 15)

Figure 15 reveals that when a resource and referral agency is present in the center PSU area, the average hourly fee is significantly lower. This finding seems reasonable give the previous findings that child/staff ratio at the group level in centers with a resource and referral agency present is higher. 


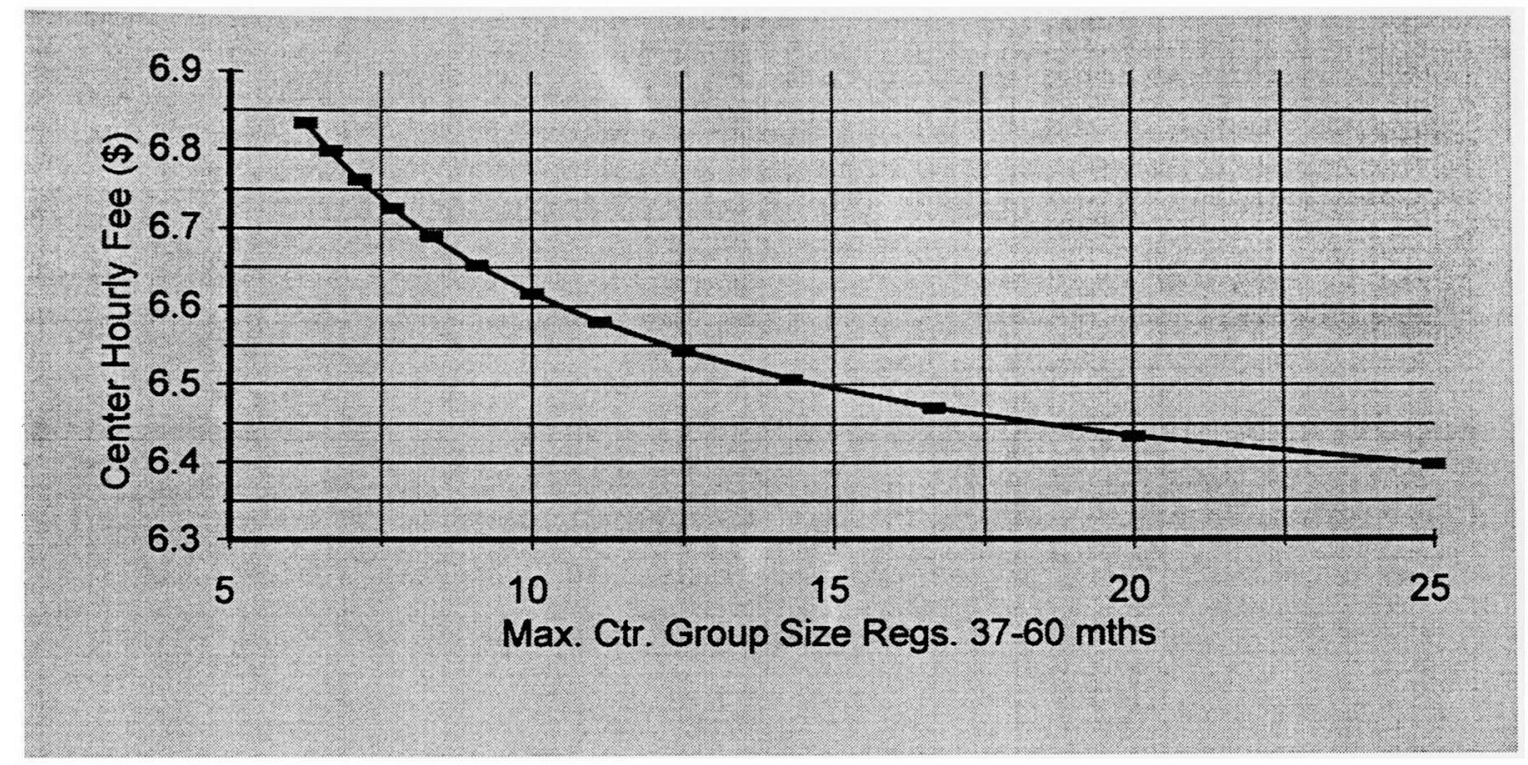

Figure 13. Effect of maximum center (Max. Ctr.) group size regulations (Regs) (37-60) months on the center hourly fee 


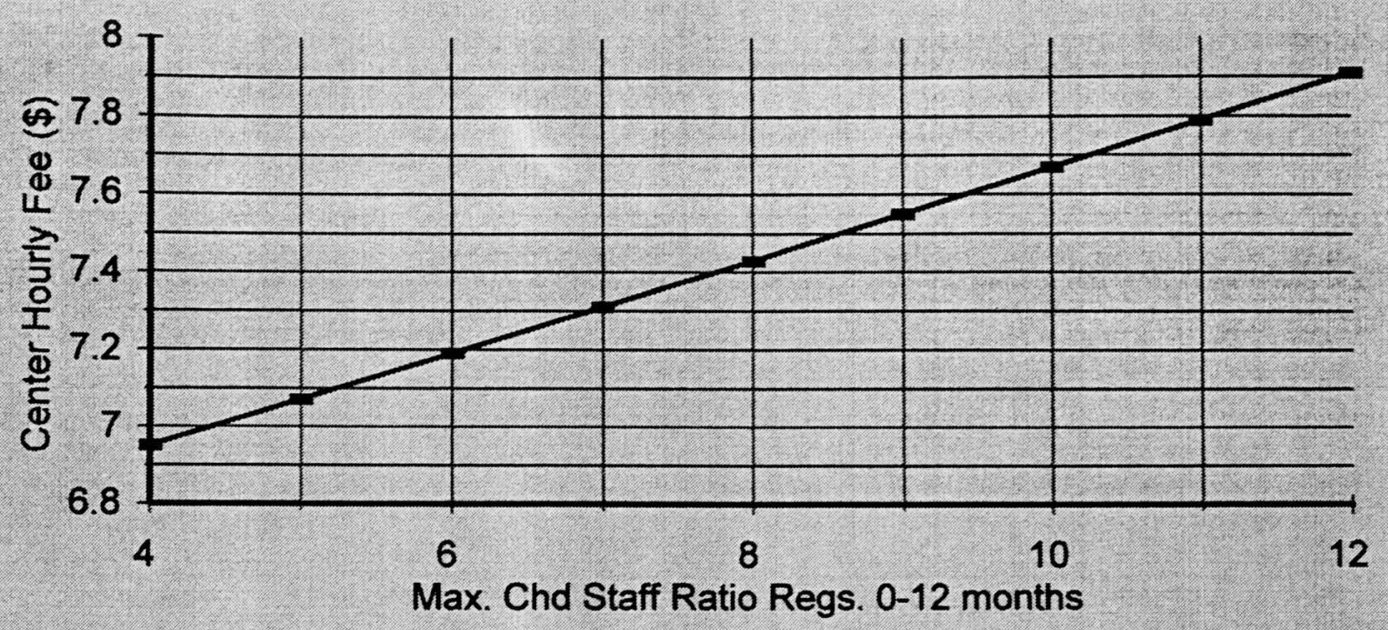

Figure 14. Effect of maximum child (Max. Chd.) staff ratio regulation (Regs.) (0-12 months) on center hourly fee. 


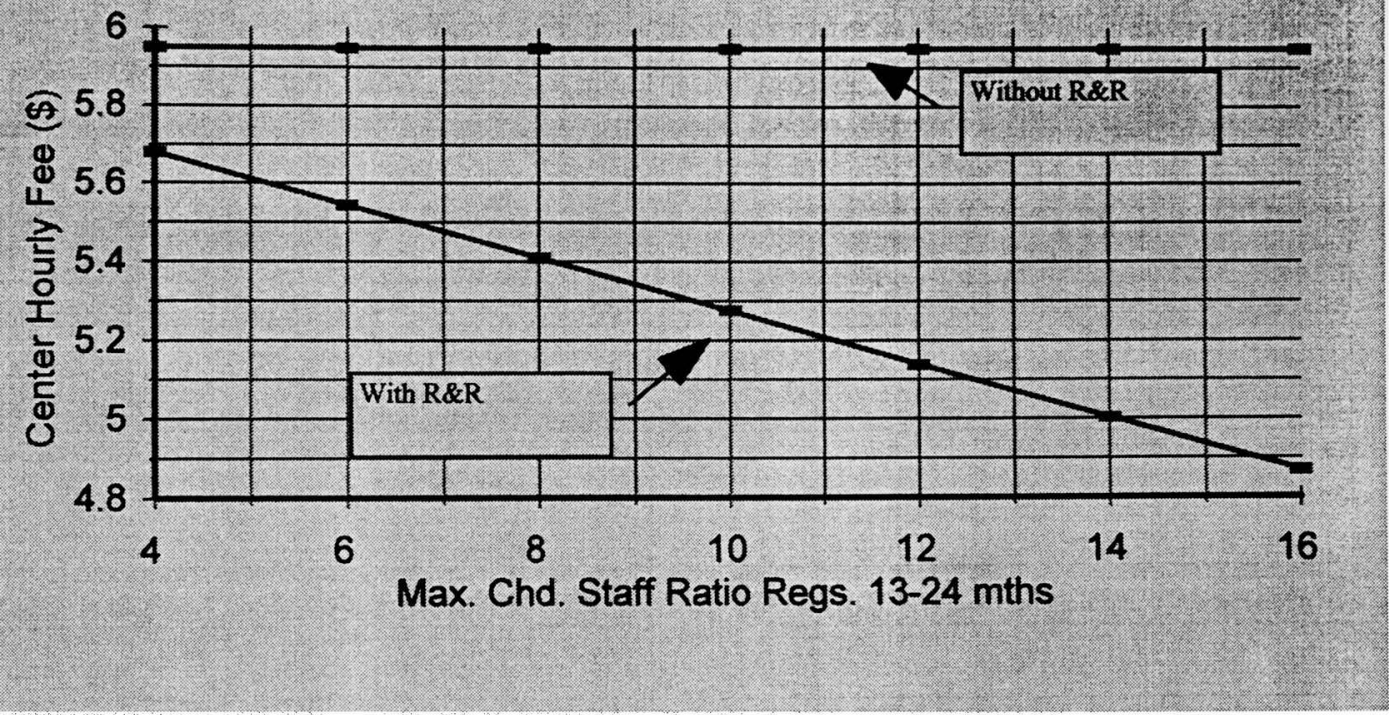

Figure 15. Interaction of resource and referral agencies and maximum child (Max. Chd.) staff ratios regulations (Regs.) for ages 13-24 months (Mths.) 


\section{Effect of prekindergarten Funds on Center Hourly Fee (Figure 16)}

The negative partial derivative means that for a unit increase in prekindergarten funds per child in poverty, the center hourly fee decreases. The elasticity of a negative 0.05 means that for one percent increase in the prekindergarten funds per poor child, there is a $0.05 \%$ decrease in the center hourly fee. Figure 16 shows the interaction of cost adjusted prekindergarten funds and maximum group size regulation for ages 25-36 months. When the maximum group size regulation for ages 25-36 months is most stringent for a given level of cost adjusted prekindergarten funds, the decrease in the center hourly price is most steep.

\section{Effect of Cost Adjusted Social Services Block Grant on Center Hourly Fee}

\section{(Figure 17)}

The positive partial derivative of 0.007 means that for a unit increase in the social services block grant per child in poverty, the center hourly fee increases.

But the interaction of cost adjusted social services block grant and maximum group size regulation for ages $25-36$ months is interesting. When the regulation is most stringent there is a steep decrease in the center hourly price of care. One of the major findings of this dissertation is the interaction of regulations and subsidy variables. 


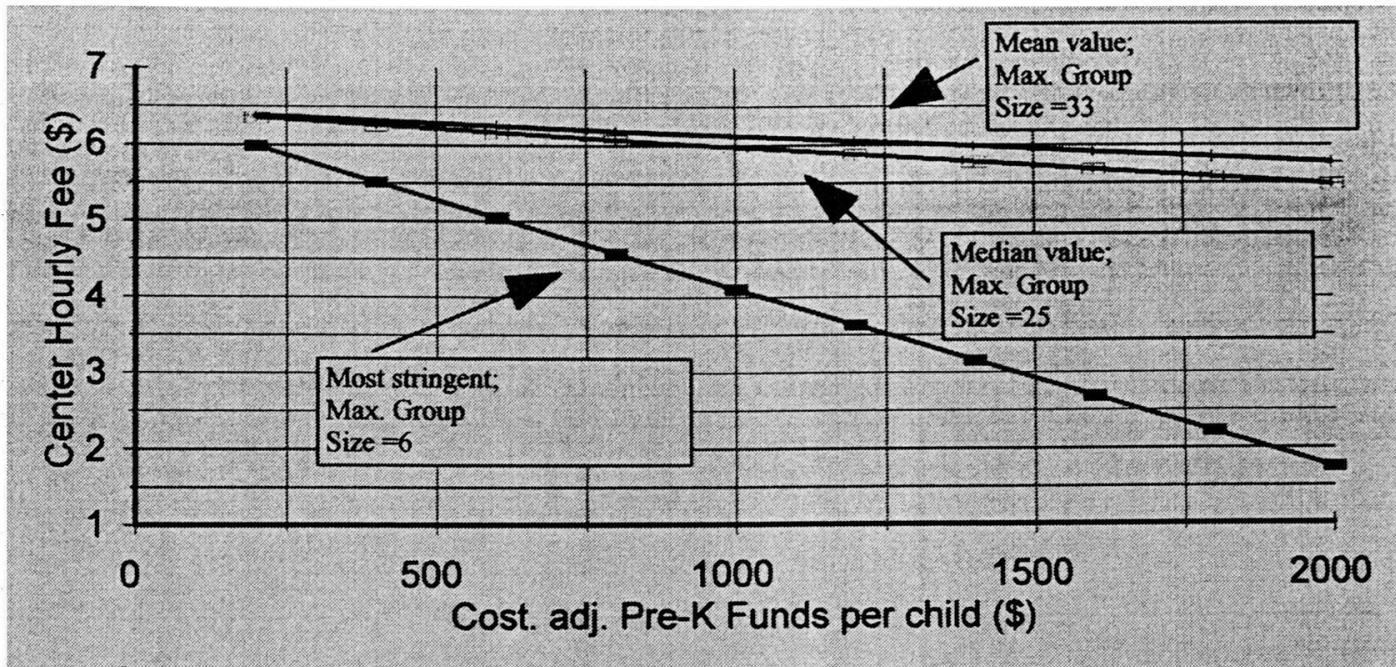

Figure 16. Interaction of cost adjusted (adj.) prekindergarten funds and maximum group size regulation for ages 25-36 months on center hourly fee 


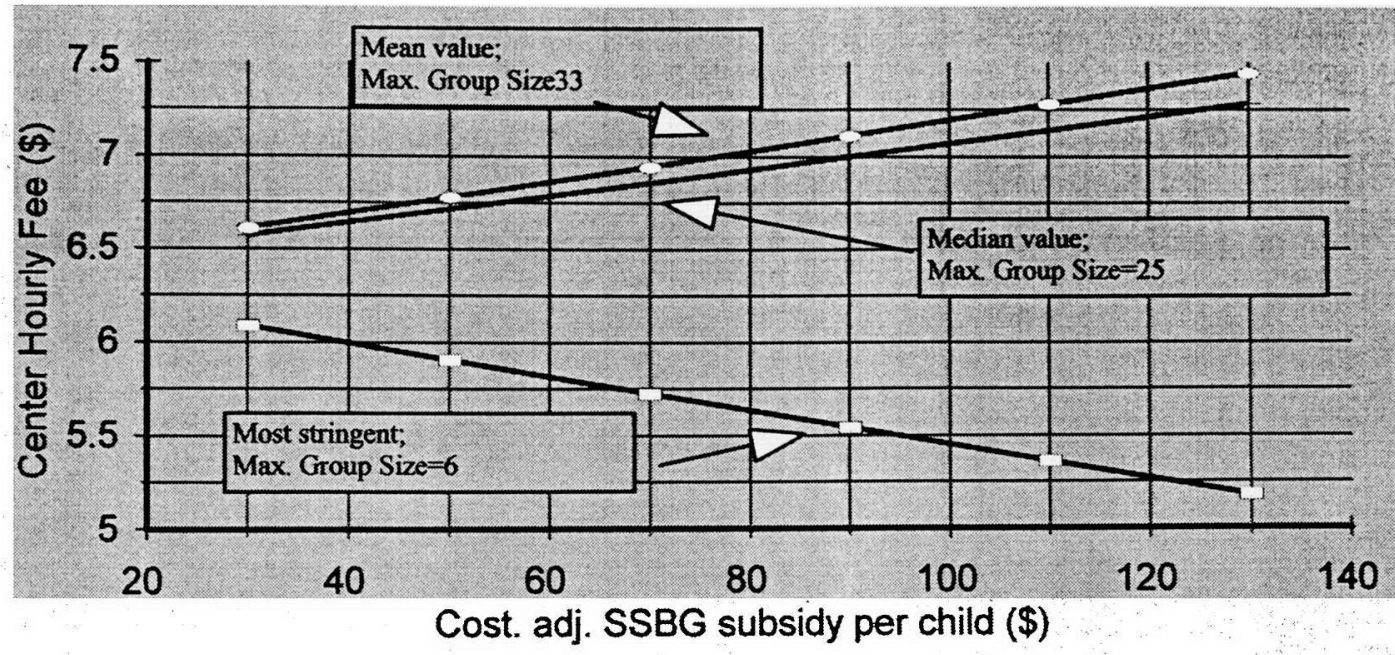

Figure 17. Interaction of cost adjusted (adj.) social services block grant (SSBG)

subsidy and maximum group size regulation for ages 25-36 months on center hourly fee 


\section{POLICY IMPLICATIONS}

Subsidies Among subsidies, only the state subsidy has a significant effect on the child/staff ratio at the group level. As the amount of state subsidy per poor child increases the child/staff ratio decreases. We can conclude that subsidies have a desirable effect on quality of care. It is interesting to note that only state subsidies have a significant effect on quality. It is also worth noting the interaction between regulatory and subsidy variables. When the regulatory variables are very stringent the effect on quality of care is vigorous. The same finding also applies to the effect on price of care. When the regulatory variables are most stringent the effect on price of care is most dramatic.

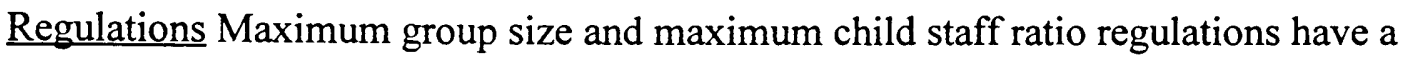
significant effect on quality and price of care. When the maximum center group size regulation for 25-36 months becomes more stringent, the child/staff ratio at the group level decreases. Another important finding is the interaction of presence of resource and referral agencies in the center PSU area and the maximum group size regulations. When the maximum group size regulation for ages 13-24 months becomes more stringent and when a resource and referral agency is present, the child/staff ratio increases at the group level. This reveals that resource and referral agencies are doing their job as providers of consumer information effectively. Another major finding is that if the center is located in a rural area the child/staff ratio is lower. Maximum group size regulations have a negative effect on center hourly fee. Maximum child/staff regulations have a mixed effect on center hourly price. 
Maximum child/staff regulations for age group 13-24 months and 37-60

months have a negative effect on price. Maximum child/staff regulations for age group $0-12$ months and $25-36$ months have a positive effect on price. This is surprising. Findings also indicate that the center average hourly price is lower when there is a resource and referral agency present. Resource and referral agencies have a desirable effect on price of care.

Center Sponsorship Another major finding is the interaction of geographic location and nature of center sponsorship. The child/staff ratio at the group level is significantly lower when there is such an interaction. 


\section{CHAPTER SEVEN}

\section{SUMMARY AND CONCLUSIONS}

Findings suggest that among subsidies only the state subsidy has a significant negative effect on the quality of care. As the amount of state subsidy per poor child increases the child/staff ratio decreases. Subsidies have no significant effect on the price of care except for prekindergarten and social services block grant. Prekindergarten funds have a negative effect and social services block grant has a positive effect on price. The finding about the significant interaction of regulations and subsidy variable provides scope for future research. One reason may be that this dissertation does not differentiate on the basis of age groups of children. Subsidies may significantly affect the price of care of infants and toddlers, because of the high cost of care for these age groups.

Maximum group size and maximum child staff ratio have a significant effect on quality and price of care. When the maximum group size regulations become stringent, the child/staff ratio decreases. An interesting finding is that as the regulation for maximum group size for age groups 13-24 months and 25-36 months become stringent, the child/staff ratio for the center increases. This shows that regulations have spillover effects. Maximum child/staff regulations have a mixed effect on center hourly price. Maximum child/staff regulations for age group 13-24 months and 37-60 months have a negative effect on price. Maximum child/staff regulations for age group 0-12 months and 25-36 months have a positive effect on price. 
The findings also suggest that the presence of an $R \& R$ agency has a significant effect on the quality of care. The child staff ratio is higher when an R\&R agency is present. This reveals that $R \& R$ agencies provide information on the availability of child care to parents.

Geographic location also plays a significant role in affecting the quality of care in centers. The interaction of geographic location and sponsored centers is significant. The child/staff ratio is significantly lower.

One of the major limitations of this study is that it does not differentiate on the basis of age groups of children. For example, subsidies may significantly affect the price of care of infants and toddlers, because of the high cost of care for these age groups. Regulations of quality of care will also affect each age group differently. Future studies differentiating on the basis of age groups of children will helpful.

Another limitation of this study is that since 1990, especially with the passing of the new welfare law there have been major changes in the child care subsidies. The number of subsidies have increased and researchers can devote their attention towards finding out the effect of these new subsides on the price and quality of care.

In conclusion we can say that this dissertation has revealed some major findings but with the passing of the new welfare law there is tremendous scope for additional research. 


\section{BIBLIOGRAPHY}

(1991, $2{ }^{\text {nd }}$ quarter). Cost of Living Index: Comparative Data for 308 Urban Areas. American Chamber of Commerce Researchers Association, 24(2).

Adams, G., \& Sandfort, J. (1994). First Steps, Promising Futures: State PreKindergarten Initiatives in the Early 1990's. Washington, DC.: Children's Defense Fund.

Adams, G., \& Sandfort, J. (1992). State Investments in child care and early childhood education. Washington, DC.: Children's Defense Fund.

Arnett, J. (1989). Caregivers in Day-Care Centers: Does Training Matter? Journal of Applied Developmental Psychology, 10, 541-552.

Becerra, R. M., \& Chi, I. (1992). Child Care preferences among lowincome minority families. International Social Work, 35(1), 35-47.

Berger, M. C., \& Black, D. A. (1992). Child Care Subsidies, Quality of Care and the Labor Supply of Low-Income, Single mothers. Review of Economics and Statistics, 74(4), 635-642.

Blau, D. M., \& Robbins, P. K. (1988). Child care costs and Family Labor Supply. Review of Economics and Statistics, 70(3), 374-381.

Blau, D. M., \& Robins, P. K. (1989, May). Fertility, Employment, and Child-Care Costs. Demography, 26(2), 287-299.

Brayfield, A. A., Deich, S. G., \& Hofferth, S. L. (1993). Caring for Children in Low-Income Families: A substudy of the National Child Care Survey, 1990 . Washington, DC.: The Urban Institute Press.

Brayfield, A., \& Hofferth, S. L. (1995, March). Balancing the Family Budget : Differences in Child Care Expenditures by Race/Ethnicity, Economic Status, and Family Structure. Social Science Quarterly, 76(1), 158-177.

Burchinal, M., Lee, M., \& Ramey, C. (1989). Type of Day-Care and Preschool : Intellectual Development in Disadvantaged Children. Child Development, 60, 128-137.

Burtless, G. (1994). Paychecks or Welfare checks, Can AFDC recepients support themselves. Brookings Review, 12(4), 34-37. 
Chipty, T., \& Witte, A.D. (1994). Economic effects of quality regulations in the day care industry (Working Paper no. 4953). Cambridge, Mass.: National Bureau of Economic Research.

Chipty, T. (1995 May). Economic Effects of Quality Regulation in the DayCare Industry. American Economic Review, 85(2), 419-424.

Committee on Ways \&Means, U.S. House of Representatives. (1991). 1991 Green Book. Washington, DC.: U.S. Government Printing Office.

Connelly, R., Hofferth, S., \& Maynard, R. (1989, ). The Child Care Market: Supply. Demand, Price and Expenditures. Paper presented at the Family Impact Seminar.

Connelly, R. (1992). The Effect of Child Care Costs on Married Women's Labor Force Participation. Review of Economics and Statistics, 74(1),83-90

Culkin, M., Morris, J. R., \& Welburn, H. S. (1991). Quality and True Cost of Child Care. Journal of Social Issues, 47(2), 71-86.

Curry, M.A.., Executive Director, Childcare Resources, Birmingham, Alabama. (1996). Survey of resource and referral agencies in existence. 1990 and 1996. (Limited to 100 PSUs in NCCS/PCCS survey).

Darlington, R. B., Royce, J. M., Snipper, A. S., \& Lazar, I. (1980, April 11). Preschool Programs and Later School Competence of Children from LowIncome Families. Science, 208, 202-204.

DeWoody, M.(1994). Making Sense of Federal Dollars: A Funding Guide for Social Service Providers. Washington, DC.: Child Welfare League of America.

Duncan, G., \& Hill, R. C. (1975). Modal Choice in Child Care Arrangements. Five Thousand American Families:Patterns of Economic Progress, III, 235-258.

Duncan, G. J., \& Hill, R. C. (1977). The Child Care Mode Choice of Working Mothers. Five Thousand American Families: Patterns of Economic Progress, V, 379-388.

Fronstin P, \& Wissoker, D. (1994). The Effect of the Availability of LowCost Child Care on the Labor Supply of Low-Income Women. Paper presented at the Annual Meeting of the Population Association of America, Miami, FL. 
Garfinkel, I., Meyer, D., \& Wong, P. (1990). The potential of child care tax credits to reduce poverty and welfare recipiency. Population Research and Policy Review, 9(1), 45-63.

Gordon, L. H. (1983). Day Care Tangle: Unexpected outcomes when programs interact. Journal of Policy Analysis and Management. 2(4), 531-541.

Gormley, W. J. (1991). State regulations and the availability of child care services. Journal of Policy Analysis and Management, 10(1), 78-95.

Greene, W. (1993). Econometric Analysis (Second ed.). New York:Macmillan.

Gustafsson, S., \& Stafford, F. (Winter 1992). Child Care Subsidies and Labor Supply in Sweden. The Journal of Human Resources, XXVII(1), 204-230.

Hagen, J. L., \& Lurie, I. (1992). Implementing JOBS: Initial State Choices . Albany, New York: The Nelson A. Rockfeller Institute of Government, State University of New York.

Hagen, J. L., \& Lurie, I. (1993). Child Care Services and JOBS:

Local Implementation. Albany, New York: The Nelson A. Rockefellar Institute of Government, State University of New York.

Hagy, A. P. (1992). Child Care Quality: Hedonic Prices, Demand, and the Effects of Government Subsidization. , Duke University.

Hayes, C. D., Palmer, J. L., \& Zaslow, M. J. (1990). Who Cares for America's Children: Child Care Policy for the 1990's. Washington, DC.: National Academy Press.

Hendry, D. F., \& Richard, J.-F. (1982). On the Formulation of Empirical Models in Dynamic Econometrics. Journal of Econometrics, 20, 3-33.

Hendry, D. F., \& Richard, J.-F. (1983). The Econometric Analysis of Economic Time Series. International Statisitical Review, 51, 111-163.

Hendry, D. F., \& Wallis, K. F. (Eds.). (1984). Econometrics and Quantitative Economics. Oxford: Basil Blackwell.

Hofferth, S., \& Phillips, D. A. (1987). Child Care in the United States, 1970 - 1995. Journal of Marraige and the Family, 49(3), 559-571. 
Hofferth, S. L., \& Phillips, D. A. (1991). Child Care Policy Research. Journal of Social Issues, 47(2), 1-13.

Hofferth, S. L., \& Wissoker, D. A. (1992). Price, Quality, and Income in Child Care Choice. The Journal of Human Resources, XXVII(1).

Hofferth, S. L. (1993). 101st Congress: An emerging agenda for children in poverty. In J. Chafel (Ed.), Child Poverty and Public Policy (pp. 203-243). Washington, DC.: Urban Institute Press.

Hofferth, S. L., \& Deich, S. G. (1994). Recent U.S. Child Care and Family Legislation in Comparative Perspective. Journal of Family Issues, 15(3), 424448.

Hofferth, S. L. (1995). Caring for Children at the Poverty Line. Children and Youth Services Review, 17(Nos 1/2), 61-90.

Kagan, S. L. (1991). Examining Profit and Nonprofit Child Care: An Odyssey of Quality and Auspices. Journal of Social Issues, 47(2), 87-104.

Kimmel, J. (1995). The Effectiveness of Child Care Subsidies in encouraging the welfare-to-work transition of low income single mothers. American Economic Review, 85(2), 271-275.

Kisker, E., Hofferth, S., Phillips, D., \& Farquhar, E. (1991). A profile of child care settings: Early education and care in 1990. Washington, DC.: U.S. Department of Education.

Kisker, E., \& Maynard, R. (1991). Quality, Cost, and Parental Choice of Child Care. In D.Blau (Ed.), The Economics of Child Care. New York:Russell Sage Foundation.

Larner, M., \& Mitchell, A. (1992). Meeting the Child Care needs of lowincome Families. Child and Youth Care Forum, 21(5), 317-334.

Lee, V. E., Schnur, E., \& Brooks-Gunn, J. (1988). Does Head Start Work? A 1-Year Follow-up Comparison of Disadvantaged Children Attending Head Start, No Preschool, and Other Preschool Programs. Developmental Psychology, 24(2), 210-222. 
Lee, V. E., Brooks-Gunn, J., Schnur, E., \& Liaw, F-R. (1990). Are Head Start Effects Sustained? Longitudinal Follow-up Comparison of Disadvantaged Children attending Head Start, No Preschool, and Other Preschool Programs. Child Development, 61, 495-507.

Lehrer, E. (1983). Determinants of Child Care Mode Choice: An Economic Perspective. Social Science Research, 12, 69-80.

Leibowitz, A., Waite, L. J., \& Witsberger, C. (1988, May). Child Care for Preschoolers: Differences by Child's Age. Demography, 25(2), 205-220.

Leibowitz, A., Klerman, J. A., \& Waite, L. J. (1992, Winter ). Employment of New Mothers and Child Care Choice: Differences by Children's Age. The Journal of Human Resources. XXVII(1), 112-133.

Marshall, N. L. \& Marx, F. (1991). The Affordability of Child Care for the Working Poor. Families in Society:The Journal of Contemporary Human Services, 72(1), 202-271.

Maynard, R. (1990). The Child Care Challenges for Low-Income Families. New York: The Rockefeller Foundation.

McCartney, K., Scarr, S., Phillips, D., \& Grajek, S. (1985). Day Care as Intervention: Comparisons of Varying Quality Programs. Journal of Applied Developmental Psychology, 6, 247-260.

Meyers, M. K., \& Van Leuwen, K. (1992, March). Child Care preferences and choices- Are AFDC recipients unique? Social Work Research and Abstracts, 28(1), 28-34.

Meyers, M.K. (1995). Child care, parental choice, and consumer education in JOBS welfare-to-work programs. Social Service Review, 69(4) 679-702.

Michalopoulos, C., Robins, P. K., \& Garfinkel, I. (1992, Winter). A Structural Model of Labor Supply and Child Care Demand. The Journal of Human Resources, XXVII(1), 166-203.

Mitchell, A. (1989). Old Baggage, New Visions Shaping policy for early childhood programs. Phi Delta Kappan, 70(9), 665-672. 
Mitchell , A., Seligson, M., \& Marx, F. (1989). Early Childhood Programs And The Public Schools: Between Promise and Practice. Dover, Massachusetts: Auburn House Publishing Company.

Mocan, N. (1995, May). Quality-Adjusted Cost Functions for Child-Care Centers. American Economic Review, 85(2), 409-413.

Morgan, G. (1989). State liability insurance requirements and regulatory information (Table 3). Massachusetts: Work/Family Directions, Inc.

Morse, A., \& Steisel, S. (1990). Child Care: A summary and analysis of new federal programs and tax credits. 101st Congress in Review. (State-Federal Issue Brief Vol. 3, No. 8). Denver, Colorado: National Conference of State Legislatures.

Mukerjee, S., \& Witte, A. D. (1990). Provision of Child Care: Cost Functions for Profit Making and Not-for-Profit Day Care Centers. Journal of Productivity Analysis, 4, 145-163.

Mukerjee, S., \& Witte, A. D. (1992). Measurement of Output and Quality Adjustment in the Day-Care Industry. Chicago and London: The University of Chicago Press.

National Governors' Association, Center for Policy Research. (1990). Taking Care: State Developments in Child Care. Washington, DC.: National Governors' Association.

National Head Start Association. (1993). Investing in Quality: The impact of the Head Start Expansion and Improvement Act of 1990 in its first year of implementation. Alexandria, Virginia.

Offner, P., Adams, G. C., \& Johnson, C. M. (1991). Child Care and the Family Support Act: Should states reimburse unlicensed providers? Public Welfare, 49(2), 6-12.

Parker, M.D. (1989). Vouchers for day care of children: Evaluating a model program. Child Welfare, 68(6), 633-643.

Phillips, D., Scarr, S., \& McCartney, K. (1987). Child-Care Quality and Children's Social Development. Developmental Psychology. 23(4), 537-543.

Phillips, D. A. (1991). Children in Poverty: Children Development and Public Policy. Cambridge: Cambridge University Press. 
Phillips, D. A., Voran, M., Kisker, E., \& Whitebook, M. (1994). Child Care for Children in Poverty: Opportunity or Inequity? Child Development, 65, 472-492.

Poersch, N., Adams, G., \& Sandfort, J. (1994). Child Care and Development: Key Facts. Washington, DC.: Children's Defense Fund.

Posner, J. K., \& Lowe Vandell, D. (1994). Low Income children's after school care: Are there beneficial effects of after-school programs? Child Development, 65(2), 440-456.

Powell, I., \& Cosgrove, J. (1992, Summer ). Quality and Cost in Early Childhood Education. The Journal of Human Resources, XXVII(3), 472-484.

Preston, E. A. (1993). Efficiency, Quality, and Social Externalities in the Provision of Day Care: Comparisons of Nonprofit and For-Profit Firms. The Journal of Productivity Analysis, 4, 165-182.

Queralt, M., \& Witte, A.D. (1996, June). Impact of public policies on child/staff ratios (Working Paper). Miami, FL: Florida International University.

Ramanathan, R. (1995). Introductory Econometrics with Applications. (Third Ed ed.). Fort Worth: The Dryden Press.

Ribar, D. C. (1992). Child Care the the Labor supply of married women-Reduced form evidence. Journal of Human Resources, 27(1), 134-165.

Robins, P. K. (1990). Federal Financing of Child Care: Alternative Approaches and Economic Implications. Population Research and Policy Review, 9(1), 65-90.

Rose-Ackerman, S. (1983). Unintended consequences: Regulating the Quality of Subsidized Day Care. Journal of Policy Analysis and Management. 3(1), 14-30.

Schnur, E., Brooks-Gunn, J., \& Shipman, V. C. (1992). Who Attends Programs Serving Poor Children? The Case of Head Start Attendees and Nonattendees. Journal of Applied Developmental Psychology, 13, 405-421.

Sonenstein, F. L., \& Wolf, D. A. (1991). Satisfaction with Child Care: Perspectives of Welfare Mothers. Journal of Social Issues, 47(2), 15-31. 
Spiegelman, R. G., \& Robins, P. K. (1978 January). An Econometric Model of the Demand for Child Care. Economic Inquiry, XVI, 83-94.

Steinschneider, J., Campbell, N. D., \& Williams, V. L. (1994). Making Care Less Taxing:Improving State Child and Dependent Care Tax Provisions . Washington D.C.: National Women's Law Center.

Trachtman, R. (1991). Early Childhood Education and Child Care: Issues of At-risk children and families. Urban Education, 26(1), 25-62.

U.S. Bureau of the Census-- Consolidated federal funds report on CD-ROM. Fiscal Year 1984-1993 [machine-readable data file]. (1994). Washington, DC.: U.S. Bureau of the Census.

U.S. General Accounting Office (GAO). (1992). States face difficulties enforcing standards and promoting quality child care (GAO/HRD-93-13). Washington, DC.

U.S. General Accounting Office (GAO). (1994). Child Care: Child care subsidies increase likelihood that low-income mothers will work (GAO-HEHS-95-20). Washington, DC.

U.S. General Accounting Office (GAO). (1994). Child Care: Current system could undermine goals of welfare reform. Testimony before the Subcommittee on Human Resources, Committee on Education and Labor, and Congressional Caucus for Women's Issues, House of Representatives (GAO/T-HEHS-94-238). Washington, DC.

U.S. General Accounting Office (GAO). (1995). Child Care: Narrow subsidy porgrams create problems for mothers trying to work. Testimony before the Subcommittee on Early Childhood, Youth and Families, Committee on Economic and Educational Opportunities, House of Representatives (GAO/T-HEHS-95-69). Washington, DC.

Waite, L. J., Leibowitz, A., \& Witsberger, C. (1991). What Parents Pay For: Child Care Characteristics, Quality, and Costs. Journal of Social Issues. 47(2), 33-48.

Walker, J. R. (1992, Winter ). New Evidence on the Supply of Child Care: A Statistical Portrait of Family Providers and an Analysis of their Fees. Journal of Human Resources, XXVII(1), 41-69. 
Whitebook, M., Howes, C., \& Phillips, D. (1989). Who Cares? Child Care Teachers and the Quality of Care in America. Executive Summary, National Child Care Staffing Study. Berkeley, CA: Child Care Employee Project.

Whitebook, M., Phillips, D., \& Howes, C. (1993). National Child Care Staffing Study Revisited: Four Years in the Life of Center-Based Child Care. Oakland, CA: Child Care Employee Project.

Yaeger, K. E. (1979). Cost, Convenience and Quality in Child Care Demand. Children and Youth Services Review, 1, 293-313.

Zaslow, M. (1991). Variation in Child Care Quality and Its Implications for Children. Journal of Social Issues, 47(2), 125-138. 


\section{VITA}

October 3, 1961

1981

1985

1988

1991

1992-1997
Born, Madras, India

Bachelor of Commerce

University of Madras

Madras, India

Master of Commerce

University of Madras

Madras, India

Master of Philosophy in Commerce

University of Madras

Madras, India

Master of Business Administration

Wright State University

Dayton, $\mathrm{OH}$

Doctorate in Public Administration

Florida International University

Miami, FL 